$s$

HNF-43821

Revision 3

\title{
Hydrogen Generation from Sludge Sample Bottles Caused by Radiolysis and Chemistry with Concentration Determination in a SWB or Drum for Transport
}

Prepared for the U.S. Department of Energy

Assistant Secretary for Environmental Management

Contractor for the U.S. Department of Energy under Contract DE-AC06-08RL14788

\section{CH2MHILL}

Plateau Remediation Company

P.O. Box 1600

Richland, Washington 99352 
HNF-43821

Revision 3

EDC \#: PRC-EDC-10-45750

\section{Hydrogen Generation from Sludge Sample Bottles Caused by Radiolysis and Chemistry with Concentration Determination in a SWB or Drum for Transport}

Document Type: TR

D. L. Riley

Ascendent Engineering \& Safety Solutions

Date Published

March 2010

Prepared for the U.S. Department of Energy

Assistant Secretary for Environmental Management

Contractor for the U.S. Department of Energy

under Contract DE-AC06-08RL14788

\section{CH2MHILL}

Plateau Remediation Company

P.O. Box 1600

Richland, Washington
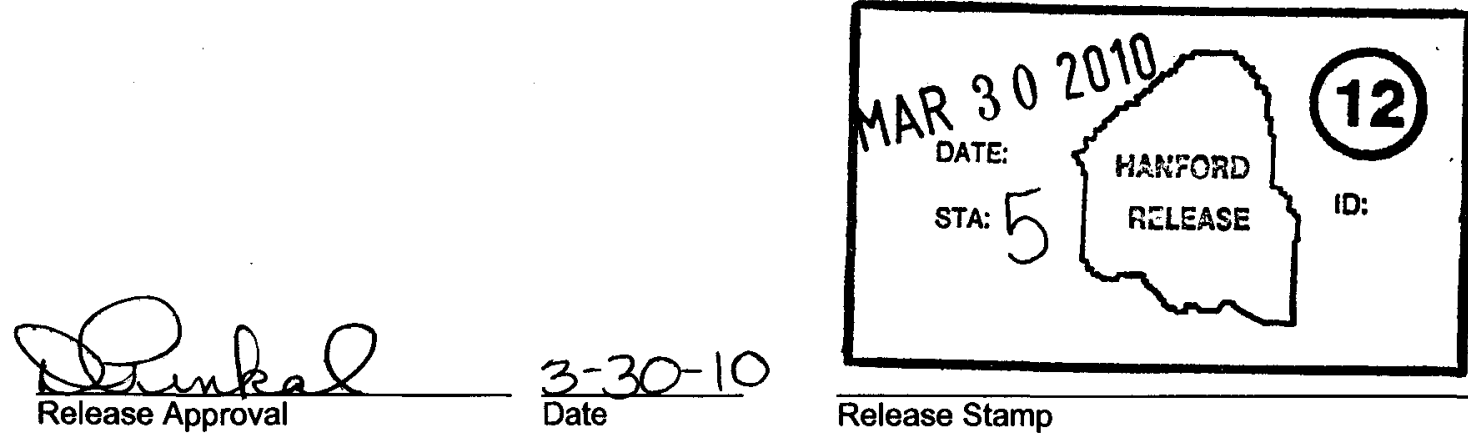

Release Stamp

Approved for Public Release;

Funther Dissemination Unlimited 
HNF-43821

Revision 3

\section{TRADEMARK DISCLAIMER}

Reference herein to any specific commercial product, process,

or service by trade name, trademark, manufacturer, or

otherwise, does not necessarily constitute or imply its

endorsement, recommendation, or favoring by the United

States Government or any agency thereof or its contractors or

subcontractors.

This report has been reproduced from the best available copy.

Printed in the United States of America

Total Pages: $\quad 50$

All trademarks contained within are the properties of the respective owners. 
(1) Document Number

HNF -43821

Page 1 of 1

(2) Title

Hydrogen Generation from Sludge Sample Bottles Caused by Radiolysis and Chemistry with Concentration Determination in a SWB or Drum for Transport

Change Control Record

\begin{tabular}{|c|c|c|}
\hline \multirow{2}{*}{$\begin{array}{c}\text { (3) } \\
\text { Revision }\end{array}$} & \multirow{2}{*}{ (4) Description of Change - Replace, Add, and Delete Pages } & Authorized for Release \\
\hline & & (5) DA/TA \\
\hline 0 & Initial Release of engineering analysis per PRC-EDC-09-43822. & $\begin{array}{l}\text { AE Bridges } \\
\text { S/AE Bridges } \\
11 / 23 / 2009\end{array}$ \\
\hline 1 & $\begin{array}{l}\text { Complete revision of engineering analysis, incorporating } \\
\text { comments from reviewers, per PRC-EDC-09-44072. Added section on } \\
\text { thermal load (chemical and radioactive). }\end{array}$ & $\begin{array}{l}\text { AE Bridges } \\
12 / 18 / 2009\end{array}$ \\
\hline 2 & $\begin{array}{l}\text { Complete revision of engineering analysis, incorporating comments from reviewers, per } \\
\text { PRC-EDC-10-44704. Added information regarding plutonium water reactions and from } \\
\text { PNNL Letter Report 46497-RPT14, "Enthalpies and Free Energies of Reaction for Uranium } \\
\text { Phases and Metals of Interest to Transportation of K Basin Sludge." }\end{array}$ & $\begin{array}{l}\text { AE Bridges } \\
02 / 03 / 2010\end{array}$ \\
\hline 3 RS & $\begin{array}{l}\text { Complete revision of engineering analysis, incorporating } \\
\text { comments from DOE reviewer (s), per PRC-EDC-10-45750. }\end{array}$ & $\begin{array}{l}\mathrm{AE} \text { Bridges } 3 / 25 / 10 \\
\text { aluris.Budfe }\end{array}$ \\
\hline & & \\
\hline & & \\
\hline & & \\
\hline 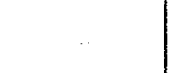 & & \\
\hline & & \\
\hline & & \\
\hline & & \\
\hline & & \\
\hline & & \\
\hline & & \\
\hline & & \\
\hline & & \\
\hline & & \\
\hline & & \\
\hline & & \\
\hline & & \\
\hline & & \\
\hline
\end{tabular}




\section{HNF-43821 Rev.3 CHPRC Calculation Cover Sheet and Revision Summary}

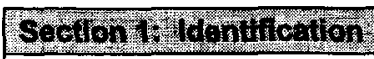

1. Project Identifier

\section{Modification Description Title/Subject \\ Hydrogen Generation from Sludge Sample Bottles \\ Caused by Radiolysis and Chemistry with Concentration \\ Determination in a SWB or Drum for Transport}

\section{Use of Form}

[X] Calculation [ ] Engineering Analysis [ ] Software Installation [ ] Technical Basis [ ] Other

\section{Job Title \\ Hydrogen Generation from Sludge Sample Bottles Caused by Radiolysis and Chemistry with Concentration Determination in a SWB or Drum for Transport}

8. Calculation Number
HNF-43821

6. WBS Number NA
3. Page 1 of 46

\section{Independent Verification Required? 13 . Performance Category (PC)}
$[\mathrm{X}]$ Yes
[ ] No
[ ] 0
[ ] 1
[ ] 2
[ ] 3
[X] N/A

\begin{tabular}{|c|c|c|c|c|c|c|}
\hline \multicolumn{7}{|c|}{ Sector 2, Prepraton reviar, and Aperoval } \\
\hline $\begin{array}{l}14 . \\
\text { Rev. } \\
\text { No. }\end{array}$ & 15. & 16. Originator & 17. Checker & $\begin{array}{l}\text { 18. Approver: Design } \\
\text { Authority or System } \\
\text { Engineer }\end{array}$ & $\begin{array}{l}\text { 19. Supersedes } \\
\text { Calc. No. or Rev. } \\
\text { No. }\end{array}$ & $\begin{array}{l}\text { 20. Field } \\
\text { Confirmation } \\
\text { Required? }\end{array}$ \\
\hline \multirow[t]{6}{*}{3} & Print Name & D. L. Riley & A. E. Bridges & W. S. Edwards & \multirow{3}{*}{ NA } & \multirow{3}{*}{$\begin{array}{l}{[] \text { Yes }} \\
{[\mathrm{X}] \text { No }}\end{array}$} \\
\hline & Sign & $=\operatorname{mithey}$ & \multirow{2}{*}{ Qheis. Butges } & hesermat & & \\
\hline & Date & $324 / 2010$ & & $3 / 25 / 10$ & & \\
\hline & Print Name & & & & & \multirow{3}{*}{$\begin{array}{l}{[\text { Y Yes }} \\
{[\text { ] No }}\end{array}$} \\
\hline & Sign & & & & & \\
\hline & Date & & & & & \\
\hline \multicolumn{7}{|c|}{ Serifon 3 Revision summary } \\
\hline $\begin{array}{l}21 . \\
\text { Rev. } \\
\text { No. }\end{array}$ & \multicolumn{5}{|c|}{ 22. Description/Reason for Revision } & $\begin{array}{l}\text { 23. Affected } \\
\text { Pages }\end{array}$ \\
\hline 0 & \multicolumn{5}{|c|}{$\begin{array}{l}\text { This calculation determines the hydrogen concentration in a SWB or drum with sludge sample bottles. The } \\
\text { hydrogen results from radiolysis and chemistry from the sludge sample bottles inside a Superpig or Piglet. } \\
\text { Two Super pigs are placed within a SWB while two Piglets are placed within a drum. }\end{array}$} & ALL \\
\hline 1 & \multicolumn{5}{|c|}{$\begin{array}{l}\text { Complete revision to incorporate comments from DOE reviewer(s). Added section on thermal load from } \\
\text { radiolysis and chemical reaction. }\end{array}$} & ALL \\
\hline 2 & \multicolumn{5}{|c|}{$\begin{array}{l}\text { Complete revision to incorporate comments from DOE reviewer(s). Added information regarding plutonium } \\
\text { water reactions and from PNNL Letter Report 46497-RPT14, "Enthalpies and Free Energies of Reaction for } \\
\text { Uranium Phases and Metals of Interest to Transportation of K Basin Sludge." }\end{array}$} & ALL \\
\hline 3 & \multicolumn{5}{|c|}{ Complete revision to incorporate comments from DOE reviewer(s). } & ALL \\
\hline \multirow{2}{*}{\multicolumn{4}{|c|}{ Registration Stamp (as applicable): }} & \multicolumn{2}{|c|}{ Classification Review: } & \\
\hline & & & & Ire/Date: 18 & & $-29-10$ \\
\hline
\end{tabular}




\section{Hydrogen Generation from Sludge Sample Bottles \\ Caused by Radiolysis and Chemistry with Concentration Determination in a SWB or Drum for Transport}

CONTENTS

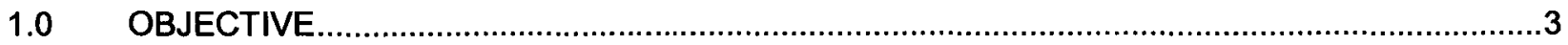

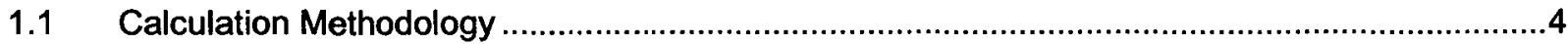

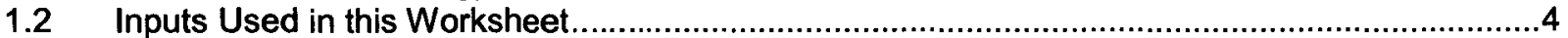

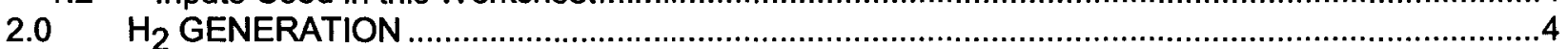

$2.1 \mathrm{H}_{2}$ Generation from the Chemistry of Uranium Metal and Water ......................................5

2.1.1 Sludge Parameters Used ..................................................................................

2.1.2 Sludge Equations Used and $\mathrm{H}_{2}$ Produced .......................................................6

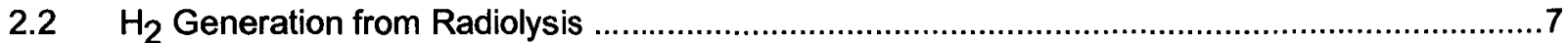

2.2.1 $\quad \mathrm{H}_{2}$ Molar Generation Rate from Radiolysis...........................................................8

2.3 Combined Total $\mathrm{H}_{2}$ Generation and Percent Contributions ..............................................8

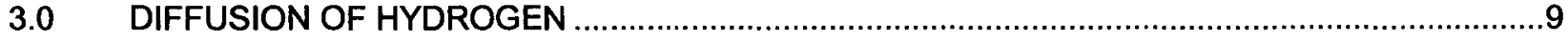

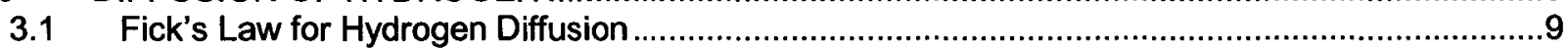

3.1.1 Diffusion Constant for Hydrogen in Air - Temperature Corrected ....................................10

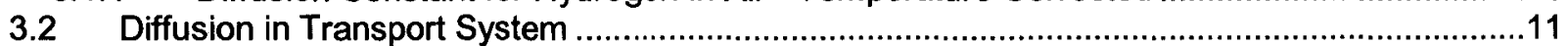

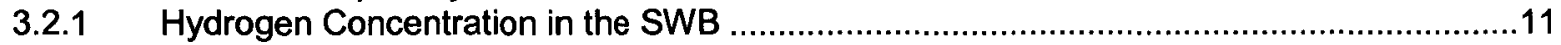

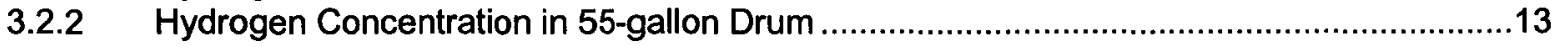

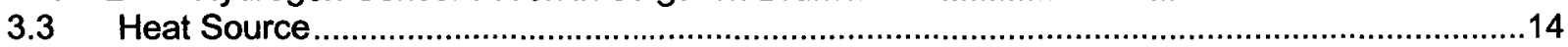

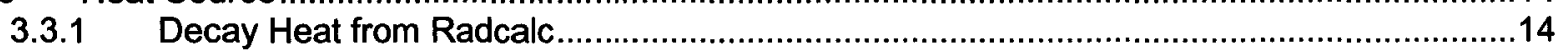

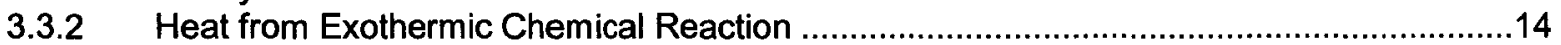

3.3.3 Total Thermal Load ........................................................................................ 17

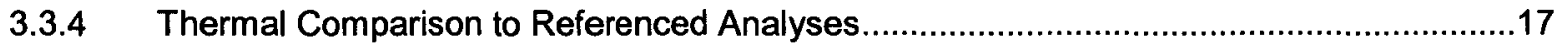

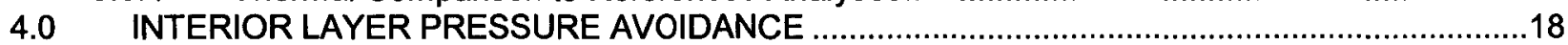

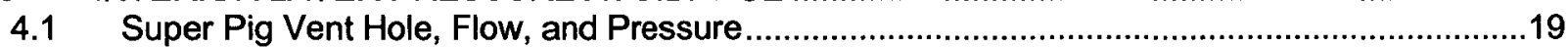

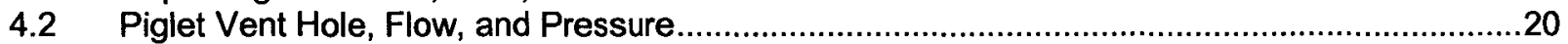

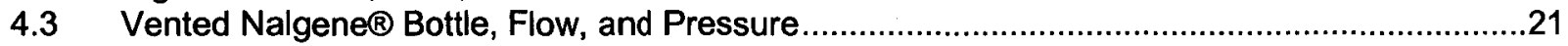

$4.4 \quad$ Vented Bag with a BOP Filter, Flow, and Pressure ......................................................21

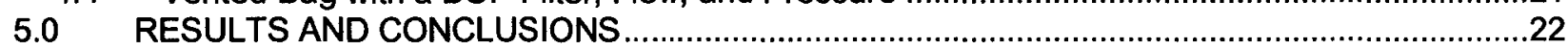

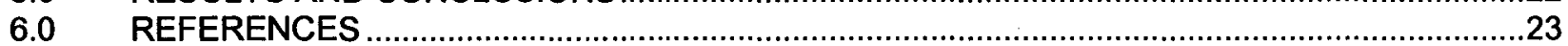

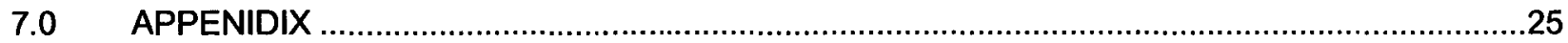

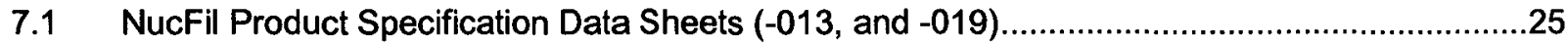

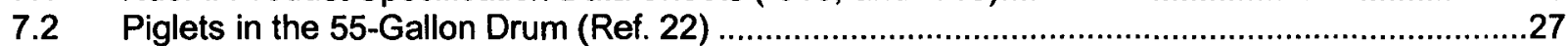

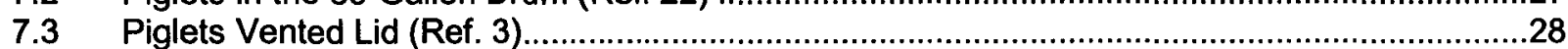

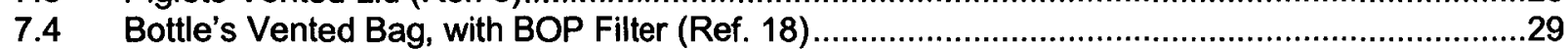

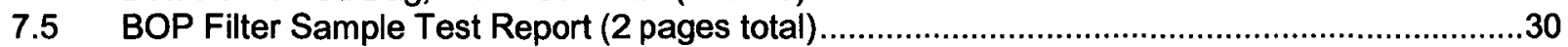

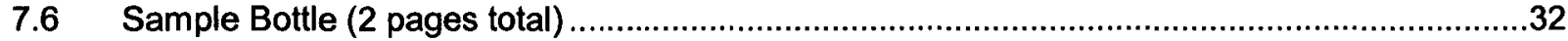

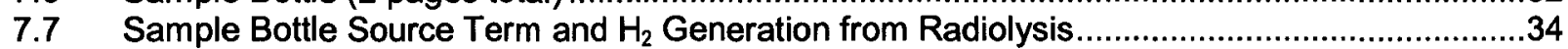

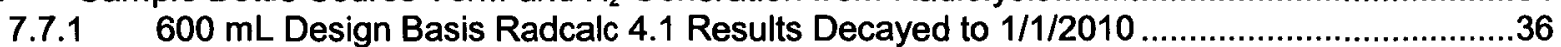

7.7.2 $600 \mathrm{~mL}$ Design Basis Radcalc 4.1 Results Decayed Nominal 15 day ............................41

7.8 PNNL Supplied Data on Plutonium Dioxide Enthalpies and Free Energies of Reaction ...........46 


\subsection{OBJECTIVE}

A volume of $600 \mathrm{~mL}$ of sludge, in $4.1 \mathrm{~L}$ sample bottles (Appendix 7.6), will be placed in either a Super Pig (Ref. 1) or Piglet (Ref. 2, 3) based on shielding requirements (Ref. 4). Two Super Pigs will be placed in a Standard Waste Box (SWB, Ref. 5), as their weight exceeds the capacity of a drum; two Piglets will be placed in a 55-gallon drum (shown in Appendix 7.2). The generation of hydrogen gas through oxidation/corrosion of uranium metal by its reaction with water will be determined and combined with the hydrogen produced by radiolysis. The hydrogen concentration in the 55-gallon drum and SWB will be calculated to show that the lower flammability limit of $5 \%$ hydrogen is not reached. The inner layers (i.e., sample bottle, bag and shielded pig) in the SWB and drum will be evaluated to assure no pressurization occurs as the hydrogen vents from the inner containers (e.g., shielded pigs, etc.).

The reaction of uranium metal with anoxic liquid water is highly exothermic; the heat of reaction will be combined with the source term decay heat, calculated from Radcalc, to show that the drum and SWB package heat load limits are satisfied.

This analysis does five things:

1. Estimates the $\mathrm{H}_{2}$ generation from the reaction of uranium metal with water

2. Estimates the $\mathrm{H}_{2}$ generation from radiolysis (using Radcalc 4.1)

3. Combines both $\mathrm{H}_{2}$ generation amounts, from Items 1 and 2, and determines the percent concentration of $\mathrm{H}_{2}$ in:

a. the interior of an SWB with two Super Pigs, and

b. the interior of a 55-gallon drum with two Piglets

4. From the combined gas generation rate, shows that the pressure at internal layers is minimal

5. Calculates the maximum thermal load of the package, both from radioactive decay of the source and daughter products as calculated/reported by Radcalc 4.1, and from the exothermic reaction of uranium metal with water

Current analysis restrictions and assumptions:

- Steady state, no functions of time

- $\mathrm{H}_{2}$ generation calculated based on:

$\circ$ one temperature, but the temperature is selectable

- one volume, $600 \mathrm{~mL}$

- The Design Basis inventory is used to calculate:

- the $\mathrm{H}_{2}$ production from the chemical reaction of water with uranium metal

- the $\mathrm{H}_{2}$ production from radiolysis

\section{Definitions used:}

Define a cc:

$$
\begin{aligned}
& \mathrm{cc}:=\mathrm{cm}^{3} \\
& \rho_{\mathrm{U}}:=19.0 \frac{\mathrm{gm}}{\mathrm{cc}} \\
& \mathrm{R}_{\mathrm{g}}:=8.3145 \frac{\mathrm{J}}{\mathrm{K} \cdot \mathrm{mole}} \\
& \mathrm{P}:=1 \mathrm{~atm}
\end{aligned}
$$$$
\text { (Ref. 6, pg B44) }
$$

Gas constant:

(Ref. 6, pg F-245)

Ambient pressure: 
I As both packages and inner layers are vented, the ambient pressure will always be assumed $1 \mathrm{~atm}$.

\subsection{Calculation Methodology}

This report was prepared using the MathCAD ${ }^{\mathrm{TM}}$ program to perform most calculations. This report includes many instances where output from that program is inserted into the text to provide numbers that support the conclusion of this report. That MathCAD ${ }^{\mathrm{TM}}$ source file is available upon request.

\subsection{Inputs Used in this Worksheet}

The default sludge volume will be $600 \mathrm{~mL}$, which is the per-sample-bottle maximum sludge amount. The default temperature will be three different values that will allow the equations to be simultaneously solved to show the results from these three temperatures. The three temperatures correspond to:

- $115^{\circ} \mathrm{F}$ The assumed ambient temperature of the sludge

- $\quad 145^{\circ} \mathrm{F}$ From Section 3.2.2.1, the assumed temperature of the sludge, based on the maximum temperature for a 55-gallon drum, with solar insolation, assuming a $115^{\circ} \mathrm{F}$ ambient air temperature (from Ref. 7)

- $157^{\circ} \mathrm{F}$ From Section 3.2.1.1, the assumed temperature of the sludge, based on the maximum temperature of the SWB, with solar insolation, assuming a $115^{\circ} \mathrm{F}$ ambient air temperature (from Ref. 8)

Assumed sludge volume: (per sample bottle)

$$
\mathrm{V}_{\text {sludge }}:=600 \cdot \mathrm{ml} \quad \mathrm{V}_{\text {sludge }}=600 \cdot \mathrm{cc}
$$

Assumed temperatures:

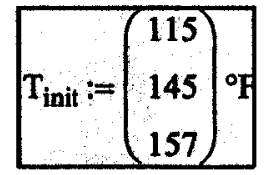

$$
\mathrm{T}_{\text {init }}=\left(\begin{array}{c}
46.1 \\
62.8 \\
69.4
\end{array}\right) \cdot{ }^{\circ} \mathrm{C}
$$

\section{$2.0 \quad \mathrm{H}_{2}$ GENERATION}

| The hydrogen generation will be calculated from two sources, the chemistry of the uranium metal - water interaction and from radiolysis.

In Pacific Northwest National Laboratory's (PNNL) report "Enthalpies and Free Energies of Reaction for Uranium Phases and Metals of Interest to Transportation of K Basin Sludge" (Ref. 9) an evaluation of the hydrogen generation from chemical reactions within the sludge other than the uranium metal-water (the aluminum-water and zirconium-water reactions) showed that "the gas generation testing results with sludge provide no evidence that appreciable Al or $\mathrm{Zr}$ metal reacted with water to generate $\mathrm{H}_{2}$ over the I temperature range of 40 to $95^{\circ} \mathrm{C}$." (Ref. 9, section 5).

Since "no evidence" was observed for the generation of $\mathrm{H}_{2}$ gas from Al or $\mathrm{Zr}$, the PNNL laboratory tests accounted for all $\mathrm{H}_{2}$ gas generated. Thus the use of the rate equation in section 2.1.2 will be used to account for all $\mathrm{H}_{2}$ gas produced, other than that by radiolysis. 


\section{HNF-43821 Rev. 3}

\section{1 $\mathrm{H}_{2}$ Generation from the Chemistry of Uranium Metal and Water}

\subsubsection{Sludge Parameters Used}

The sludge parameters were obtained from Ref. 10, Table 2-3 "Properties for Container and Settler Sludge" the "Uranium Metal Fraction in Settled Sludge - Non-Segregated." Ref. 10 establishes the basis for all settler sludge design activities and is appropriate to use for this evaluation.

Design Basis values for uranium metal fraction in sludge:

$$
\begin{aligned}
& \mathrm{UM}_{\mathrm{con}}:=0.052 \cdot \frac{\mathrm{gm}}{\mathrm{cc}} \\
& \mathrm{M}_{\mathrm{MU}}:=\mathrm{UM}_{\mathrm{con}} \cdot \mathrm{V}_{\text {sludge }}=31.2 \cdot \mathrm{gm}
\end{aligned}
$$

The resulting mass of metallic uranium in the sludge is:

From Ref. 11, Table 4-5b "Reactive Sludge Particle Size for Uranium Metal - Segregated," given the

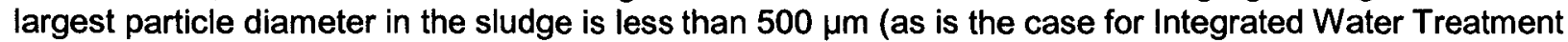
System (IWTS) Settler sludge) then the average effective particle diameter is $375 \mu \mathrm{m}$. That value is then used to calculate the total number of uranium metal particles in the container and the total uranium surface area in the sample bottle, which is used to determine the overall uranium metal-water reaction rate.

Uranium metal particle diameter:

$$
\begin{aligned}
& \mathrm{d}:=375 \cdot \mu \mathrm{m}=1.23 \times 10^{-3} \mathrm{ft} \\
& V_{0} p_{\text {part }}:=\frac{\pi}{6} \cdot \mathrm{d}^{3}=2.761 \times 10^{-5} \cdot \mathrm{cc} \\
& \mathrm{M}_{\text {part }}:=V_{\mathrm{o}} \mathrm{p}_{\text {part }} \cdot \rho_{U}=5.246 \times 10^{-4} \cdot \mathrm{gm}
\end{aligned}
$$

Volume of a single particle:

Mass of a single particle:

Surface area of a single particle:

$$
\mathrm{A}_{\text {single }}:=\pi \cdot \mathrm{d}^{2}=4.418 \times 10^{-3} \cdot \mathrm{cm}^{2}
$$

Number of particles:

$$
\mathrm{N}_{\text {part }}:=\text { ceil }\left(\frac{M_{M U}}{M_{\text {part }}}\right)=59472
$$

Note: "ceil" is the MathCAD ${ }^{\mathrm{TM}}$ abbreviation for the mathematical function "ceiling" which rounds toward positive infinity generating the nearest integer greater than or equal to the number of particles in question.

Surface area of all particles:

$$
A_{\text {all }}:=N_{\text {part }} \cdot A_{\text {single }}=262.7 \cdot \mathrm{cm}^{2}
$$

The hydrogen gas produced from chemical reaction is determined by the Sludge Treatment Project (STP) rate law (Ref. 11). The rate law represents the culmination of reviewing 60 years of technical literature and is based on a survey of 32 studies resulting in 128 data points. The data points are between the temperatures of $24^{\circ} \mathrm{C}$ and $350{ }^{\circ} \mathrm{C}$. The entire 128-point dataset is plotted in Figure 2.2 of Ref. 12 and closely follows an Arrhenius dependence on temperature (the logarithm of the rate is proportional to the inverse absolute temperature) over the range of temperature. As there is some data spread over the range of temperature relative to the Arrhenius fit, an upper and lower bound is provided to allow a $95 \%$ confidence limit for the rate equation. The upper and lower bound for $95 \%$ confidence is approximately a factor of 3 and is very nearly a constant over the temperature range and is known as the Enhancement Factor. 
As discussed in Appendix A of Reference 13, the overall technical basis for using the literature rate for the uranium metal in sludge is supported by the central limit tendency for averages. A sludge sample bottle holds the equivalent of many sludge samples used in the gas generation experiments (note: sample sizes ranged from -10 to $400 \mathrm{~g}$ of sludge). As demonstrated in Figure 2.2 of Ref. 12, there is wide, nonsystematic scatter in the literature data, with some points above and some points below the average. It is expected that a collection of independent sludge samples (equivalent to what may be contained in $600 \mathrm{~mL}$ of sludge in a sample bottle) will behave like the literature average.

Over the past 12 years gas generation and uranium corrosion testing has been conducted in support of the STP with genuine sludge, irradiated N-Reactor uranium metal fuel, and un-irradiated uranium metal beads (Ref. 12). In all cases, with sludge and N-Reactor fuel, the measured rate from the testing has been within or below the $95 \%$ confidence bounds established from the STP rate law. In one case, with natural uranium beads in a grout waste form, the observed rate was slightly greater than the upper $95 \%$ confidence bound.

Consistent with the above from Ref. 11, Table 4-10 "Reaction Rate Enhancement Factor for Reaction of U Metal with Oxygen-Free Water," for the design basis Enhancement Factor (the high value for $95 \%$ confidence) is:

Enhancement Factor:

$\mathrm{EF}:=3$

[Note: from Ref. 11, Table 4-10, the rate enhancement factors for design basis are the same as used for safety basis]

\subsubsection{Sludge Equations Used and $\mathrm{H}_{2}$ Produced}

From Ref. 11, Table 4-9 "KE \& KW Sludge Reaction Rate for Uranium Metal Particulate" shows the equations for weight loss per unit of time and the surface area basis equation $\left(R_{c}\right)$.

From section 1.1:

$$
\mathrm{T}_{\text {init }}=\left(\begin{array}{c}
115 \\
145 \\
157
\end{array}\right) \cdot{ }^{\circ} \mathrm{F} \quad \mathrm{T}_{\text {init }}=\left(\begin{array}{c}
46.1 \\
62.8 \\
69.4
\end{array}\right) \cdot{ }^{\circ} \mathrm{C}
$$

Rate constant:

$$
\left.\mathrm{R}_{\mathrm{c}}:=\left(\frac{\mathrm{mg}}{\mathrm{cm}^{2} \cdot \mathrm{hr}}\right) \cdot 10^{\left(9.975-\frac{3565 \mathrm{~K}}{\mathrm{~T}_{\text {init }}}\right.}\right)=\left(\begin{array}{l}
0.0644 \\
0.2305 \\
0.3708
\end{array}\right) \cdot \frac{\mathrm{mg}}{\mathrm{cm}^{2} \cdot \mathrm{hr}}
$$

Weight loss:

$$
\text { Rate }:=A_{\text {all }} \cdot E F \cdot R_{c}=\left(\begin{array}{c}
50.7 \\
181.7 \\
292.3
\end{array}\right) \cdot \frac{\mathrm{mg}}{\mathrm{hr}} \begin{array}{r}
115^{\circ} \mathrm{F} \\
\text { for } 145^{\circ} \mathrm{F} \\
157^{\circ} \mathrm{F}
\end{array}
$$


Two moles of hydrogen are produced for every mole of uranium (i.e., $\mathrm{U}+2 \mathrm{H}_{2} \mathrm{O}=\mathrm{UO}_{2}+2 \mathrm{H}_{2}$ ), so the $\mathrm{H}_{2}$ production is:

$$
\begin{aligned}
& \text { Moles of } \mathrm{H}_{2} \text { produced: } \quad \mathrm{n}_{\mathrm{H}_{2} \text { chem }}:=\operatorname{Rate} \cdot \frac{1 \mathrm{~mol}}{238.05 \cdot \mathrm{gm}} \cdot \frac{2 \mathrm{~mol}}{1 \mathrm{~mol}}=\left(\begin{array}{l}
4.26 \times 10^{-4} \\
1.53 \times 10^{-3} \\
2.46 \times 10^{-3}
\end{array}\right) \cdot \frac{\mathrm{mol}}{\mathrm{hr}} \\
& \mathrm{n}_{\mathrm{H}_{2} \text { chem }}=\left(\begin{array}{cc}
1.18 \times 10^{-7} \\
4.24 \times 10^{-7} \\
6.82 \times 10^{-7}
\end{array}\right) \cdot \frac{\mathrm{mol}}{\mathrm{sec}} \begin{array}{c}
115^{\circ} \mathrm{F} \\
\text { for } 145^{\circ} \mathrm{F} \\
157^{\circ} \mathrm{F}
\end{array}
\end{aligned}
$$

\section{2 $\mathrm{H}_{2}$ Generation from Radiolysis}

Ref. 10 provides the source term that is being used for all settler sludge design activities and is appropriate to use for this evaluation. Ref. 14 was used for the water transported in the sample bottles in addition to the sludge. The following summarizes the related applications of these for the analyses:

1) The sludge source data is taken from Ref. 10, Table 2-2a Sludge Radionuclide Inventories (Decayed to 5-31-1998). The sludge inventory is shown in Table 7.7.1 in Appendix 7.7.

2) The volume in the $4.1 \mathrm{~L}$ bottle that is not sludge is conservatively assumed to be $K E$ canister water, from Ref. 14, Table 4-1 Nominal Inventory for K Basin Water Associated with Sludge. The "nominal" water source term from this table is used for the design basis inventory.

KE canister water was selected because it has conservative radionuclide content (i.e., ${ }^{137} \mathrm{Cs}$ concentration is an order of magnitude greater than that in $\mathrm{KW}$ canister water) and some of the settler sludge originated in the KE Basin. It could be argued that it would be appropriate to use the lower water radionuclide values provided in TI-015 (Ref. 11) Table 4-22 when the settler sludge is in the IWTS settler tanks. However, it would not be appropriate when the settler sludge is retrieved into Engineered Container SCS-CON-230. The TI-015 (Ref.11) Table 4-22, in the 'Note:' to the table, states its values are valid for flowing basin water or sludge staged in a large container such as the Weasel Pit. For small to moderate size vessels or containers, such as the Engineered Container and the sample bottles, Table 422 directs the use of HNF-SD-SNF-TI-009 Table 4-1, which is used here.

The water inventory is shown in Table 7.7.1 in Appendix 7.7.

The inventory shown in Table 7.7.1 in Appendix 7.7 was further decayed by a nominal 15 days to establish a minimal-time Radcalc run to estimate the initial heat and gas generated. The inventory was also decayed in Radcalc 4.1 to $1 / 1 / 2010$. The largest $\mathrm{H}_{2}$ generation and thermal heat load, from either the 15-day decayed inventory or the inventory decayed to $1 / 1 / 2010$ (4,234 days) is conservatively used. Both Radcalc results are included in the Appendix.

An Excel spreadsheet was used to determine the specific inventory for an arbitrary volume of sludge, with the remaining volume consisting of water, as defined above. The results from the spreadsheet were used as inputs for Radcalc which resulted in the $\mathrm{H}_{2}$ generation results from radiolysis used in this report. The spreadsheet produced the source inventory for $600 \mathrm{~mL}$ of sludge (with the remaining volume water) and is shown in Appendix 7.7, Table 7.7.1. The results of the $600 \mathrm{~mL}$ Radcalc 4.1 run are shown in Appendix 
7.7, Sections 7.7.1 and 7.7.2 for the Design Basis for the two different decay times. In this report, only $600 \mathrm{~mL}$ of sludge is considered.

Radcalc performs gas calculations at standard pressure and temperature $\left(1 \mathrm{~atm}\right.$ and $\left.0{ }^{\circ} \mathrm{C}\right)$. When volume calculations are used throughout this report, the volume flow rate will be temperature adjusted.

Appendix 7.7, Sections 7.7.1 and 7.7.2 contain the complete Radcalc 4.1 output files for $600 \mathrm{~mL}$ Design Basis sludge for the two different decay times. Of the two output files, the largest $\mathrm{H}_{2}$ generation rate for the $600 \mathrm{~mL}$ Design Basis sludge is: $0.1002 \mathrm{cc} / \mathrm{hr}$.

\subsection{1 $\mathrm{H}_{2}$ Molar Generation Rate from Radiolysis}

The volumetric $\mathrm{H}_{2}$ generation value from Appendix 7.7, Sections 7.7.1 and 7.7.2 is for $0{ }^{\circ} \mathrm{C}$ (Radcalc 4.1 default), and the volumetric generation rate needs to be converted to the molar generation rate at the Radcalc 4.1 default temperature. Note that pressure, at $1 \mathrm{~atm}$, does not need to be adjusted (all layers are vented).

The default Radcalc temperature used in the generated values:

The default Radcalc pressure:

$$
\mathrm{T}_{\text {Radcalc }}:=0^{\circ} \mathrm{C}=273.15 \mathrm{~K}
$$

$\mathbf{P}=1 \mathrm{~atm}$

The volume of sludge is from the input section:

$$
\mathrm{V}_{\text {sludge }}=0.6 \cdot \mathrm{L}
$$

The max. resulting $\mathrm{H}_{2}$ generation rate is:

(Appendix 7.7, Section 7.7.2, from the nominal 15-day decay)

$$
\begin{aligned}
& \mathrm{H} 2_{\text {rad_D }}:=.1002 \cdot \frac{\mathrm{cc}}{\mathrm{hr}} \\
& \mathrm{n}_{\mathrm{H} 2 \_ \text {rad_D }}=\mathrm{H} 2_{\text {rad_D }} \frac{\mathrm{P}}{\mathrm{R}_{\mathrm{g}} \cdot \mathrm{T}_{\text {Radcalc }}}=1.242 \times 10^{-9} \cdot \frac{\mathrm{mol}}{\mathrm{s}}
\end{aligned}
$$

Moles of $\mathrm{H}_{2}$ generated from radiolysis:

$$
\mathrm{n}_{\mathrm{H} 2 \text { rad }}:=\mathrm{n}_{\mathrm{H} 2 \_ \text {rad_D }} \text { Design Basis }
$$

The Radcalc temperature at $0^{\circ} \mathrm{C}$ is used to determine the hydrogen generation from radiolysis in moles per second, and this rate will be used throughout this analysis and is temperature independent. When a volumetric rate is needed, it will be determined based on the temperature of interest in the particular analysis.

\subsection{Combined Total $\mathrm{H}_{2}$ Generation and Percent Contributions}

The two sources of hydrogen will now be combined and the resulting percent contribution of each source will be shown. 


\section{HNF-43821 Rev. 3}

Total moles of $\mathrm{H}_{2}$ produced:

(from one bottle, at

three temperatures)

$$
\mathrm{n}_{\text {total }}:=\mathrm{n}_{\mathrm{H}_{2} \text { rad }}+\mathbf{n}_{\mathrm{H}_{2} \text { chem }}=\left(\begin{array}{c}
1.20 \times 10^{-7} \\
4.25 \times 10^{-7} \\
6.83 \times 10^{-7}
\end{array}\right) \cdot \frac{\mathrm{mol}}{\mathrm{s}} \begin{array}{r}
115^{\circ} \mathrm{F} \\
\text { for } 145^{\circ} \mathrm{F} \\
157^{\circ} \mathrm{F}
\end{array}
$$

Percent contribution from radiolysis: $\quad$ cont $_{\mathrm{rad}}:=\frac{\mathrm{n}_{\mathrm{H} 2} \mathrm{rad}}{\mathrm{n}_{\mathrm{total}}}=\left(\begin{array}{l}1.0 \\ 0.3 \\ 0.2\end{array}\right) \cdot \%$

Percent contribution from chemistry: $\quad$ cont $_{\text {chem }}:=\frac{\mathrm{n}_{\mathrm{H} 2 \text { chem }}}{\mathrm{n}_{\text {total }}}=\left(\begin{array}{l}99.0 \\ 99.7 \\ 99.8\end{array}\right) \cdot \%$

Clearly, the chemical reaction is the predominant form of $\mathrm{H}_{2}$ generation.

From section 1.1:

$$
\mathrm{T}_{\text {init }}=\left(\begin{array}{c}
115 \\
145 \\
157
\end{array}\right) \cdot{ }^{\circ} \mathrm{F} \quad \mathrm{T}_{\text {init }}=\left(\begin{array}{c}
46.1 \\
62.8 \\
69.4
\end{array}\right) \cdot{ }^{\circ} \mathrm{C}
$$

Total volumetric $\mathrm{H}_{2}$ generation is:

(from one bottle)

$$
\text { Vol }_{\text {total }}:=\frac{\overline{n_{\text {total }} \cdot R_{\mathrm{g}} \cdot \mathrm{T}_{\text {init }}}}{\mathrm{P}}=\left(\begin{array}{lr}
11.28 \\
42.19 \\
69.15
\end{array}\right) \cdot \frac{\mathrm{cc}}{\mathrm{hr}} \quad \begin{array}{r}
115^{\circ} \mathrm{F} \\
157^{\circ} \mathrm{F}
\end{array}
$$

\subsection{DIFFUSION OF HYDROGEN}

The hydrogen generation rates, from radiolysis and the metal/water reaction will now be used with the law of diffusion to calculate the percent $\mathrm{H}_{2}$ concentrations inside the SWB (with Super Pigs) and inside the 55-gallon drum (with Piglets).

Only diffusion will be assumed, which is conservative, as this ignores pressure driven flow from the gas creation, temperature driven flow from temperature differences over time creating pressure differences, convection flow, or buoyant flow.

\subsection{Fick's Law for Hydrogen Diffusion}

The release of hydrogen gas $\left(\mathrm{H}_{2}\right)$ from a vented package by diffusion through air is modeled according to Fick's law of diffusion (Ref. 15), which is in the form:

where:

$$
j=Q \cdot \frac{d c}{d z}
$$




$$
\begin{aligned}
& Q=\text { Diffusion constant for hydrogen in air, } \mathrm{cm}^{2} / \mathrm{s} \\
& d c=\text { Concentration gradient across path, moles } / \mathrm{cm}^{3} \\
& d z=\text { Diffusion path length, cm } \\
& j=\text { Molar flux, moles } / \mathrm{cm}^{2} / \mathrm{s}
\end{aligned}
$$

The diffusion flow rate is given by:

$$
\dot{n}=A \cdot j
$$

where:

$$
\begin{aligned}
& A=\text { Cross-sectional area of diffusion path, } \mathrm{cm}^{2} \\
& \dot{n}=\text { Diffusion flow rate, moles/s }
\end{aligned}
$$

Substituting Fick's law into the diffusion flow rate (for $j$ ) gives the following expression for the diffusion flow rate $\dot{n}$ :

$$
\dot{n}=\left(\frac{Q \cdot A}{d z}\right) \cdot d c
$$

The quantity inside the parenthesis is defined as the diffusivity, $D$, with units $\mathrm{cm}^{3} / \mathrm{s}$ :

$$
D=\left(\frac{Q \cdot A}{d z}\right)
$$

The diffusion flow rate can now be simply expressed as:

$$
\dot{n}=D \cdot d c
$$

The driving force for hydrogen diffusion from a package is the concentration gradient between the package interior and the surrounding atmosphere, which is approximated as having a hydrogen concentration of zero. Ref. 6 lists the hydrogen concentration of atmospheric air at $0.5 \mathrm{ppm}$ by volume, or $0.00005 \mathrm{vol} \%$. In this context, $d c$ represents the overall concentration difference between the package interior and exterior and can be relabeled $\Delta c$ to distinguish it from the differential concentration gradient. Because the external hydrogen concentration can be assumed zero, $\Delta c$ is simply the hydrogen concentration inside the package, expressed in volume percent (vol\%).

The diffusion flow rate equation is solved for $d c$, the hydrogen concentration differential. It will be renamed $\Delta c$ as discussed above to represent the overall concentration difference between the package interior and exterior. Also, the diffusivity will be renamed to represent the total package diffusivity $D_{p k g}$ and the flow rate is the molar hydrogen generation rate $\dot{n}_{H_{2}}$ from combining the Radcalc 4.1 radiolysis and the uranium water chemistry interaction.

$$
\Delta c=\frac{\dot{n}_{H_{2}}}{D_{p k g}}
$$

This equation will be used to determine the volume percent of $\mathrm{H}_{2}$ in the containment boundary.

\subsubsection{Diffusion Constant for Hydrogen in Air - Temperature Corrected}

The Hydrogen diffusion constant will be corrected for the particular temperature given from the parameter input section above. 
Ref. 16, the diffusion constant for hydrogen in air at 273K is: $\quad Q_{273}:=0.611 \frac{\mathrm{cm}^{2}}{\mathrm{~s}}$

Ref. 16, Perry's Chemical Engineers' Handbook Eq. (3-133) shows that the diffusion constant is proportional to $\mathrm{T}^{1.75}$; the power to which $\mathrm{T}$ is raised depends on the actual temperature (Perry's Sixth Edition, Diffusion Coefficients, page 3-285).

The assumed temperature:

$$
\mathrm{T}_{\text {init }}=\left(\begin{array}{l}
319.3 \\
335.9 \\
342.6
\end{array}\right) \mathrm{K} \quad \mathrm{T}_{\text {init }}=\left(\begin{array}{c}
115 \\
145 \\
157
\end{array}\right) \cdot{ }^{\circ} \mathrm{F} \quad \mathrm{T}_{\text {init }}=\left(\begin{array}{c}
46.1 \\
62.8 \\
69.4
\end{array}\right) \cdot{ }^{\circ} \mathrm{C}
$$

Temperature corrected $Q$ value: $\quad Q_{\mathrm{H} 2}:=Q_{273^{\circ}}\left(\frac{T_{\text {init }}}{273 \mathrm{~K}}\right)^{1.75}=\left(\begin{array}{lr}0.804 \\ 0.878 \\ 0.909\end{array}\right) \cdot \frac{\mathrm{cm}^{2}}{\mathrm{sec}} \begin{array}{r}115^{\circ} \mathrm{F} \\ \text { for } 145^{\circ} \mathrm{F} \\ 157^{\circ} \mathrm{F}\end{array}$

\subsection{Diffusion in Transport System}

The transport system consists of a Standard Waste Box (SWB, Ref. 5), which contains two Super Pigs (Ref. 1) or a 55-gallon drum (Ref. 17, typical) that contains two shielded container assemblies, Piglets, Ref. 2 and 3. One $4.1 \mathrm{~L}$ sample bottle is placed in a vented 12 mil polyurethane bag (Ref. 18) prior to placement in the Super Pig (Ref. 1) or Piglet (Ref. 2 and 3).

The two boundaries that are being credited as the containment boundaries are the SWB for the Super Pig and the 55-gallon drum for the Piglet. Both of these boundaries are vented and the percent $\mathrm{H}_{2}$ concentration in these boundaries will be calculated.

\subsubsection{Hydrogen Concentration in the SWB}

Assume the SWB is vented with " $n$ " NucFil-019 filters, with minimum $n=2$ and maximum $n=4$. The SWB has two Super Pigs, with each Super Pig containing one sample bottle.

From manufacturers specification sheet: (for one model NucFil NFT-013 filter

$$
\mathrm{D}_{013}:=1.1 \times 10^{-5} \cdot \frac{\mathrm{mol}}{\mathrm{s}}
$$

Appendix 7.1)

From manufacturers specification sheet: (for one model NucFil NFT-019 filter

$$
\mathrm{D}_{019}:=2.4 \times 10^{-5} \cdot \frac{\mathrm{mol}}{\mathrm{s}}
$$

Appendix 7.1)

The assumed temperature: (ambient)

$$
\mathrm{T}_{\text {init }_{0}}=319.3 \mathrm{~K} \quad \mathrm{~T}_{\text {init }_{0}}=115 \cdot{ }^{\circ} \mathrm{F} \quad \mathrm{T}_{\text {init }_{0}}=46.1 \cdot{ }^{\circ} \mathrm{C}
$$

The assumed pressure:

$$
\mathbf{P}=1 \cdot \mathbf{a t m}
$$


Volumetric filter flow:

Assume the SWB has "n" filters:

The SWB has two Super Pigs:

"n" filters in parallel on SWB:

The volume percent of $H_{2}$ in the SWB is:

(For two Super Pigs in the SWB)

This is for the input parameters:

$$
\begin{aligned}
& \mathrm{D}_{\mathrm{NFT} 019}:=\mathrm{D}_{019} \cdot \frac{\mathrm{R}_{\mathrm{g}} \cdot \mathrm{T}_{\text {init }_{0}}}{\mathrm{P}}=0.629 \cdot \frac{\mathrm{cc}}{\mathrm{s}} \\
& \mathrm{n}_{\mathrm{swb}}:=2 \\
& \mathrm{n}_{\text {pigs }}:=2 \\
& \mathrm{D}_{\mathrm{swb}}:=\mathrm{n}_{\mathrm{swb}} \cdot \mathrm{D}_{019}=4.8 \times 10^{-5} \cdot \frac{\mathrm{mol}}{\mathrm{s}} \\
& \% \mathrm{SWB}_{\mathrm{H} 2 \_ \text {__PIG }}:=\frac{\mathrm{n}_{\text {pigs }} \mathrm{n}_{\text {total }}}{\mathrm{D}_{\text {swb }}}=0.5 \cdot \% \\
& \mathrm{~V}_{\text {sludge }}=600 \cdot \mathrm{mL} \quad \mathrm{T}_{\text {init }_{0}}=115 \cdot{ }^{\circ} \mathrm{F}
\end{aligned}
$$

The concentration of hydrogen in the SWB is less than $5 \%$, for the design basis sludge at $115^{\circ} \mathrm{F}$. However, the volume percent will be checked at the solar insolation temperature of the SWB.

\subsubsection{Hydrogen Concentration in the SWB at Solar Insolation Temperature}

The SWB Safety Analysis Report for Packaging (SARP Ref. 8, page xxi-xxii) shows that the maximum SWB temperature does not exceed $69^{\circ} \mathrm{C},\left(157^{\circ} \mathrm{F}\right)$ from solar insolation with an outside air temperature of $115^{\circ} \mathrm{F}$. Page B8-6 shows the maximum temperature is $154.9^{\circ} \mathrm{F}$, which is independent of the internal heat load, from 0 to 4 Watts, which bounds the sludge samples as two bottles produce 0.43 Watts (see section 3.3.3). The assumptions listed for the thermal analysis are on page B8-5 of Ref. 8. The $\mathrm{H}_{2}$ concentration in the SWB (with up to four filters) will be calculated at $157^{\circ} \mathrm{F}$, to determine if controls are needed to avoid exposure of the SWB to solar insolation.

This worksheet allows the temperature to be adjusted to any value to produce the total $\mathrm{H}_{2}$ generation. The hydrogen generation value calculated in section 2.3 for $157^{\circ} \mathrm{F}$ will now be used.

The assumed temperature:

(SWB maximum Solar)

$$
\mathrm{T}_{\text {init }_{2}}=342.6 \mathrm{~K} \quad \mathrm{~T}_{\text {init }_{2}}=157 \cdot{ }^{\circ} \mathrm{F} \quad \mathrm{T}_{\text {init }_{2}}=69.4 \cdot{ }^{\circ} \mathrm{C}
$$

The total moles of $\mathrm{H}_{2}$ produced is:

(from one bottle, at $157^{\circ} \mathrm{F}$ )

$$
\begin{aligned}
& \mathrm{n}_{\text {total }_{2}}=6.83 \times 10^{-7} \frac{\mathrm{mol}}{\mathrm{s}} \\
& \text { Vol }_{\text {total }_{2}}=69.15 \cdot \frac{\mathrm{cc}}{\mathrm{hr}}
\end{aligned}
$$

The volumetric total $\mathrm{H}_{2}$ generation is: (from one bottle, at $157^{\circ} \mathrm{F}$ )

Assume the SWB has " $n$ " filters:

$$
\begin{aligned}
& \mathrm{n}_{\text {swb_max } 13}:=3 \quad \mathrm{n}_{\text {swb_max } 19}:=2 \\
& D_{\text {swb_max } 19}:=n_{\text {swb_max_19 } 19} \cdot D_{019}=4.8 \times 10^{-5} \cdot \frac{\mathrm{mol}}{\mathrm{s}} \\
& D_{\text {swb_max } 13}:=n_{\text {swb_max_13 }} \cdot D_{013}=3.3 \times 10^{-5} \cdot \frac{\mathrm{mol}}{\mathrm{s}}
\end{aligned}
$$

"n" filters in parallel on SWB: (for -013 and -019 ) 
The volume percent of $\mathrm{H}_{2}$ in the SWB is: (For two Super Pigs in the SWB at $157^{\circ} \mathrm{F}$ with either the -013 or -019 filter).

$\% W_{H_{2} 2 \text { _PIG_157F_19 }}:=\frac{2 \mathrm{n}_{\text {total }_{2}}}{D_{\text {Swb_max } 19}}=2.8 \cdot \%$

$\% \mathrm{SWB}_{\mathrm{H} 2 \text { 2_PIG_1S7F_13 }}:=\frac{2 \mathrm{n}_{\text {total }}}{\mathrm{D}_{\text {swb_max_13 }}}=4.1 . \%$

Note that this is for the input parameters: $V_{\text {sludge }}=600 \mathrm{~mL}$, and $T_{\text {init }}=157^{\circ} \mathrm{F}$

This shows that the SWB does not need controls for solar insolation and can be shipped at ambient I temperatures as high as $115^{\circ} \mathrm{F}$ when fitted with minimum two NucFil-019 filters or equivalent, or minimum three NucFil-013 filters or equivalent.

\subsubsection{Hydrogen Concentration in 55-gallon Drum}

Assume the 55-gallon drum is vented with a single NucFil-019 filter (or equivalent) and that the drum contains two Piglets, each with one sample bottle. Assume the temperature is at the ambient $115^{\circ} \mathrm{F}$.

The assumed temperature:

(Drum ambient)

$$
\mathrm{T}_{\text {init }_{0}}=319.3 \mathrm{~K} \quad \mathrm{~T}_{\text {init }_{0}}=115 \cdot{ }^{\circ} \mathrm{F} \quad \mathrm{T}_{\text {init }_{0}}=46.1 \cdot{ }^{\circ} \mathrm{C}
$$

The drum filter:

(Assume one drum filter)

$$
D_{\text {drum }}:=D_{019}=2.4 \times 10^{-5} \cdot \frac{\mathrm{mol}}{\mathrm{sec}}
$$

The volume percent of $\mathrm{H}_{2}$ in the drum is: (For two Piglets in the drum)

$$
\% \text { Drum }_{\text {H2___PIG }}:=\frac{2 \mathrm{n}_{\text {total }_{0}}}{D_{\text {drum }}}=1.0 \cdot \%
$$

This is for the input parameters:

$$
\mathrm{V}_{\text {sludge }}=600 \cdot \mathrm{mL} \quad \mathrm{T}_{\text {init }_{0}}=115 \cdot{ }^{\circ} \mathrm{F}
$$

\subsubsection{Hydrogen Concentration in 55-gallon Drum at Solar Insolation Temperature}

The previous section shows that the 55 -gallon drum meets the less-than $5 \% \mathrm{H}_{2}$ concentration at $115^{\circ} \mathrm{F}$.

Ref. 7 shows that 55 -gallon drum surface temperatures with solar insolation can reach $145^{\circ} \mathrm{F}$ with ambient air at $115^{\circ} \mathrm{F}$, so this analysis will be done using a sludge temperature of $145^{\circ} \mathrm{F}$. This temperature is independent of the internal heat load, from 0 to 12 Watts, which bounds the sludge samples as two pigs produce 0.43 Watts (see section 3.3.3).

The hydrogen generation value calculated in section 2.3 for $145^{\circ} \mathrm{F}$ will now be used, which occurs at the maximum temperature for the drum.

For this case, a single $3 / 4$-in filter $(-019)$ will be used: 


\section{HNF-43821 Rev. 3}

The assumed temperature:

(Drum maximum Solar)

$$
\mathrm{T}_{\text {init }_{1}}=335.9 \mathrm{~K} \quad \mathrm{~T}_{\text {init }_{1}}=145 \cdot{ }^{\circ} \mathrm{F} \quad \mathrm{T}_{\text {init }_{1}}=62.8 \cdot{ }^{\circ} \mathrm{C}
$$

The total moles of $\mathrm{H}_{2}$ produced is:

(from one bottle, at $145^{\circ} \mathrm{F}$ )

$$
\mathrm{n}_{\text {total }}=4.25 \times 10^{-7} \cdot \frac{\mathrm{mol}}{\mathrm{s}}
$$

The volumetric total $\mathrm{H}_{2}$ generation is:

(from one bottle, at $145^{\circ} \mathrm{F}$ )

$$
\text { Vol }_{\text {total }_{1}}=42.19 \cdot \frac{\mathrm{cc}}{\mathrm{hr}}
$$

The volume percent of $\mathrm{H}_{2}$ in the drum is:

(For two Piglets in the drum at $145^{\circ} \mathrm{F}$ )

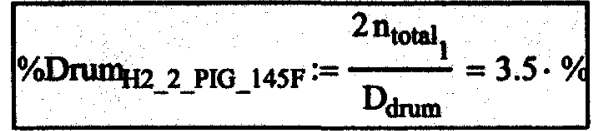

Note that this is for the input parameters: $V_{\text {sludge }}=600 \mathrm{~mL}$, and $T_{\text {init }}=145^{\circ} \mathrm{F}$

This shows that the drum does not need controls for solar insolation and can be shipped at ambient temperatures as high as $115^{\circ} \mathrm{F}$ when fitted with a single NucFil-019 filter or equivalent.

\subsection{Heat Source}

The total heat will be calculated for both exothermic chemical reaction and from the decay, as reported in the Radcalc 4.1 runs.

In Ref. 9, PNNL evaluated heat production from chemical reactions within the sludge other than the uranium metal-water reaction. PNNL specifically analyzed the aluminum-water and zirconium-water reactions, and concluded that "the gas generation testing results with sludge provide no evidence that appreciable Al or $\mathrm{Zr}$ metal reacted with water to generate $\mathrm{H}_{2}$ over the temperature range of 40 to $95^{\circ} \mathrm{C}$." PNNL further stated that hydrogen production measured in their sampling activities would have been assumed to have been produced by uranium metal, but an over-prediction of uranium metal with a corresponding under-prediction of "reactable $\mathrm{Zr}$ and $\mathrm{Al}$ metal" would only result in a small underestimate of total reaction enthalpy (Section 5 of Ref. 9).

\subsubsection{Decay Heat from Radcalc}

The decay heat from radioactive decay of the source and daughter isotopes is shown in Appendix 7.7, Sections 7.7.1 and 7.7.2 for the two different decay times. The maximum decay heat is $0.032 \mathrm{~W}$ for the $600 \mathrm{~mL}$ sample of sludge at a decay time of 15 days. Since there will be two sample bottles in each drum or SWB, the maximum radiolytic decay heat is $0.064 \mathrm{~W}$.

\subsubsection{Heat from Exothermic Chemical Reaction}

In the sections that follow it will be shown that there are small quantities of $\mathrm{Al}, \mathrm{Zr}$, and $\mathrm{Pu}$, in comparison with the quantity of $U$ in the sludge. Due to the small quantities and Ref. 9 indicating there is no evidence of appreciable reaction of these materials, the heat from exothermic chemical reaction will be ignored for $\mathrm{Al}, \mathrm{Zr}$, and $\mathrm{Pu}$.

There is a large margin between the total heat load calculated in section 3.3.3 $(0.43 \mathrm{~W}$ for the SWB and $0.29 \mathrm{~W}$ for the drum) and the heat load assumed in the referenced thermal analyses of the drum (12 W) and the SWB $(4 \mathrm{~W})$ that resulted in the maximum package temperatures with solar insolation used in this report. It was the solar insolation temperatures for the SWB and Drum, with internal heat loads of $4 \mathrm{~W}$ and $12 \mathrm{~W}$, respectively, that were used to establish the temperatures assumed in this report. The total 


\section{HNF-43821 Rev. 3}

sludge heat load would need to be on the order of ten times greater for the heat load to increase the assumed package temperature for the SWB, or thirty times greater for the heat load to increase the assumed package temperature for the Drum.

Due to these large margins, as shown in Section 3.3.2.2, the increases in the heat load that could be shown for $\mathrm{Al}, \mathrm{Zr}$, or $\mathrm{Pu}$ would have negligible effects on reducing the margin.

\subsubsection{Uranium Water Reaction}

The uranium metal in the sludge is transported with basin water in the sample container. It is assumed that the mass of water is sufficient to react all the uranium metal and is considered unlimited for the purposes of modeling the exothermic uranium metal and water reaction. The heat for the uranium-water reaction is $127.4 \mathrm{kcal} / \mathrm{mole}-\mathrm{U}$ (Ref. 19, section 8.1.2.2).

The reaction of uranium in water is represented by

(Ref. 19)

$$
\mathrm{U}+2 \mathrm{H}_{2} \mathrm{O}=\mathrm{UO}_{2}+2 \mathrm{H}_{2}+127.4 \mathrm{kcal} / \mathrm{mole} \text { of uranium }
$$

The two solar insolation temperatures:

$$
\begin{array}{ll}
\text { SWB: } & \mathrm{T}_{\text {init }_{2}}=157 \cdot{ }^{\circ} \mathrm{F} \\
\text { Drum: } & \mathrm{T}_{\text {init }_{1}}=145 \cdot{ }^{\circ} \mathrm{F}
\end{array}
$$

From section 3.2.1.1 and 3.2.2.1 (SWB and Drum):

The total moles of $\mathrm{H}_{2}$ produced is:

(from one bottle, at $157^{\circ} \mathrm{F}$ and $145^{\circ} \mathrm{F}$ )

$$
\mathrm{n}_{\mathrm{H}_{2} \text { total }}:=\left(\begin{array}{l}
\mathrm{n}_{\text {total }_{2}} \\
\mathrm{n}_{\text {total }_{1}}
\end{array}\right)=\left(\begin{array}{l}
6.833 \times 10^{-7} \\
4.252 \times 10^{-7}
\end{array}\right) \cdot \frac{\mathrm{mol}}{\mathrm{sec}} \quad \begin{aligned}
& \text { SWB@157 } \\
& { }^{\circ} \mathrm{F}
\end{aligned}
$$

Thus the moles of uranium reacted is one half the moles of hydration produced:

Moles uranium reacted:

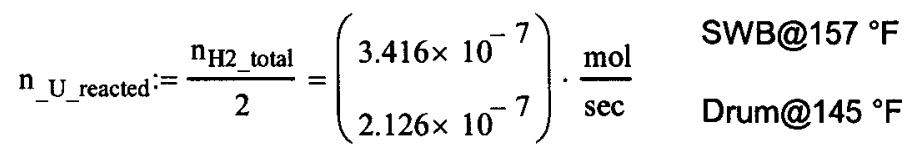

Exothermic reaction rate:

$$
U_{-} \text {thermal } \mathrm{rate}_{\mathrm{ate}}:=127.4 \cdot \frac{\mathrm{kcal}}{\mathrm{mol}} \quad \text { (per mol uranium) }
$$

The number of sample bottles in the package: $\quad n_{\text {pigs }}=2$

The exothermic heat produced is then:

(For two sample bottles, the package)

$$
\begin{aligned}
& \text { Heat }_{\text {exo_U }}:=\mathrm{n}_{\text {pigs }} \cdot \mathrm{n}_{\text {_U_reacted }} \cdot \mathrm{U}_{\text {_thermal }} \text { rate } \\
& \text { Heat }_{\text {exo_U }}=\left(\begin{array}{l}
0.364 \\
0.227
\end{array}\right) \cdot \mathrm{W} \quad \begin{array}{l}
\text { SWB@157 } \\
{ }^{\circ} \mathrm{F} \\
\text { Drum@145 }
\end{array}
\end{aligned}
$$

\subsubsection{Aluminum and Zirconium Reaction}

Section 5.0 of Ref. 9 discusses the confirmation of the corrosion resistance and lack of significant reactivity of aluminum in the $\mathrm{K}$ basin water. It also discusses how zirconium has demonstrated outstanding corrosion resistance. The ratio of $\mathrm{Al}$ and $\mathrm{Zr}$ to that of uranium will be calculated and the low quantity of $\mathrm{Al}$ and $\mathrm{Zr}$, along with its corrosion resistance, justifies ignoring the heat source from these materials. 


\section{HNF-43821 Rev. 3}

Table 2-3 of Ref. 10 shows the total uranium in the sludge is $1.34 \mathrm{~g} \mathrm{U} / \mathrm{cc}$. Table 2-5 (Ref. 10) shows the nominal chemical constituents for $\mathrm{Al}$ and $\mathrm{Zr}$. Aluminum, in the form of aluminum hydroxide, is present in the sludge at $0.125 \mathrm{~g} / \mathrm{cc}$. Zirconium is identified as not being present in the sludge by the table.

Comparing the $\mathrm{Al}$ in the sludge to the uranium:

Molecular weight of aluminum hydroxide:

$$
\mathrm{MW}_{\mathrm{Al} \_\mathrm{OH} \_}:=\left(26.982+3 \cdot 15.999+3 \cdot 1.008 \frac{\mathrm{g}}{\mathrm{mol}}=78.003 \cdot \frac{\mathrm{g}}{\mathrm{mol}}\right.
$$

Molecular weight of aluminum:

$$
\mathrm{MW}_{\mathrm{Al}}:=26.982 \cdot \frac{\mathrm{g}}{\mathrm{mol}}
$$

The ratio of aluminum in aluminum hydroxide:

$$
\text { ratio }_{\mathrm{Al}}:=\frac{\mathrm{MW}_{\mathrm{Al}}}{\mathrm{MW}_{\mathrm{Al} \_\mathrm{OH} \_}}=34.6 \cdot \%
$$

Aluminum hydroxide in settler sludge:

(Ref. 10, Table 2-5)

$$
\mathrm{Al}_{\text {hydro }}:=0.125 \cdot \frac{\mathrm{g}}{\mathrm{cc}}
$$

The portion of aluminum in settler sludge:

$$
\begin{aligned}
& \mathrm{Al}_{\text {sludge }}:=\mathrm{ratio}_{\mathrm{Al}} \cdot \mathrm{Al}_{\text {hydro }}=0.043 \cdot \frac{\mathrm{g}}{\mathrm{cc}} \\
& \mathrm{U}_{\text {sludge }}:=1.34 \cdot \frac{\mathrm{g}}{\mathrm{cc}} \\
& \text { ratio }_{\text {al_to } \_\mathrm{u}}:=\frac{\mathrm{Al}_{\text {sludge }}}{\mathrm{U}_{\text {sludge }}}=3.2 \cdot \%
\end{aligned}
$$

(Ref. 10, Table 2-3, design basis)

Ratio of aluminum to total uranium:

With such a small amount of aluminum relative to uranium in the sludge, the discussion in Ref. 9 on the corrosion resistance of aluminum in the $\mathrm{K} \mathrm{Basin}$ water, and the large margin of safety discussed in Section 3.3.2, aluminum reactions can be ignored. Also, as Ref. 10, Table 2-5 does not identify any zirconium in the settler sludge and the discussion in Ref. 9 on the outstanding corrosion resistance of zirconium, zirconium reactions will also be ignored.

\subsubsection{Plutonium Water Reaction}

The reaction of plutonium metal with water is shown (Ref. 9) to have slightly less enthalpy and Gibbs free energy to that of uranium (discussed above in section 3.3.2.1). Appendix 7.7 shows the quantity of plutonium and uranium. The ratio of the two quantities will be calculated to show that the plutonium reaction may be ignored.

Using the design basis, decayed to $1 / 1 / 2010$, Radcalc 4.1 results from Section 7.7 .1 shows the quantity, in grams, of uranium as:

$$
\begin{array}{lll}
\text { Qnt }_{\mathrm{U} 233}:=8.633 \times 10^{-8} \cdot \mathrm{gm} & \mathrm{Qnt}_{\mathrm{U} 234}:=4.853 \times 10^{-2} \cdot \mathrm{gm} & \text { Qnt }_{\mathrm{U} 235}:=4.767 \times 10^{0} \cdot \mathrm{gm} \\
\text { Qnt }_{\mathrm{U} 235 \mathrm{~m}}:=2.728 \times 10^{-9} \cdot \mathrm{gm} & \mathrm{Qnt}_{\mathrm{U} 236}:=5.323 \times 10^{-1} \cdot \mathrm{gm} & \text { Qnt }_{\mathrm{U} 237}:=4.531 \times 10^{-10} \cdot \mathrm{gm} \\
\text { Qnt }_{\mathrm{U} 238}:=6.248 \times 10^{2} \cdot \mathrm{gm} & &
\end{array}
$$

Total uranium is:

$$
\mathrm{Qnt}_{-} \text {total }_{\mathrm{U}}:=\mathrm{Qnt}_{\mathrm{U} 233}+\mathrm{Qnt}_{\mathrm{U} 234}+\mathrm{Qnt}_{\mathrm{U} 235}+\mathrm{Qnt}_{\mathrm{U} 235 \mathrm{~m}}+\mathrm{Qnt}_{\mathrm{U} 236}+\mathrm{Qnt}_{\mathrm{U} 237}+\mathrm{Qnt}_{\mathrm{U} 238}=630.1 \mathrm{gm}
$$


Using the design basis, decayed to $1 / 1 / 2010$, Radcalc 4.1 results from Section 7.7 .1 shows the quantity, in grams, of plutonium as:

$$
\begin{aligned}
& \mathrm{Qnt}_{\mathrm{PU} 238}:=1.252 \times 10^{-3} \cdot \mathrm{gm} \quad \mathrm{Qnt}_{\mathrm{PU} 239}:=1.354 \times 10^{0} \cdot \mathrm{gm} \quad \mathrm{Qnt}_{\mathrm{PU} 240}:=2.020 \times 10^{-1} \cdot \mathrm{gm} \\
& \text { Qnt }_{\text {PU241 }}:=1.451 \times 10^{-2} \cdot \mathrm{gm} \quad \text { Qnt }_{\mathrm{PU} 242}:=5.235 \times 10^{-3} \cdot \mathrm{gm}
\end{aligned}
$$

Total plutonium is:

Qnt_total $\mathrm{PU}:=\mathrm{Qnt}_{\mathrm{PU} 238}+\mathrm{Qnt}_{\mathrm{PU} 239}+\mathrm{Qnt}_{\mathrm{PU} 240}+\mathrm{Qnt}_{\mathrm{PU} 241}+\mathrm{Qnt}_{\mathrm{PU} 242}=1.6 \mathrm{gm}$

The ratio of plutonium to uranium is: $\quad$ Ratio $_{\mathrm{Pu}_{-} \text {to }-\mathrm{U}}:=\frac{\mathrm{Qnt}_{-} \text {total }_{\mathrm{PU}}}{\mathrm{Qnt}_{-} \text {total }_{\mathrm{U}}}=0.002503$ $\frac{1}{\text { Ratio }_{\text {Pu_to_U }_{-}}}=399.6$

Due to the fact that there is approximately 400 times the amount of uranium to that of plutonium, the plutonium's contribution to thermal heating and hydrogen generation will be ignored.

\subsubsection{Total Thermal Load}

The total thermal heat load is the sum of that from radiolysis and the exothermic heat of reaction of uranium with water for two sample bottles in either the drum or SWB. This is calculated as

The Radcalc 4.1 reported

thermal load (one pig):

(Appendix 7.7.1 or 7.7.2)

The total package thermal load is: (two sample bottles)

$$
\begin{aligned}
& \text { Heat }_{\text {radcalc }}:=0.032 \mathrm{~W} \\
& \mathrm{n}_{\text {pigs }}=2
\end{aligned}
$$

Heat $_{\text {total_per_package }}:=$ Heat $_{\text {exo_U }}+\mathrm{n}_{\text {pigs }} \cdot$ Heat $_{\text {radcalc }}=\left(\begin{array}{c}0.43 \\ 0.29\end{array}\right) \cdot \mathrm{W}$

SWB

Drum

\subsubsection{Thermal Comparison to Referenced Analyses}

As shown in sections 2.1.2, 2.3, and 3.3.2.1, the assumed temperature of the settler sludge determines the volumetric hydrogen gas produced and the exothermic heat load generated. As shown in section 1.2, three temperatures were assumed and used for calculations. The assumed settler sludge temperature used in this report, for the drum and SWB packages, was determined from the maximum reported temperature as shown in the Drum and SWB SARP. The Drum and SWB SARPs assumed a bounding internal heat load used in the calculations for maximum package temperature with solar insolation. For the drum, the thermal source assumed in Ref. 7 (Drum SARP, Part B, Section 8.2.2.1) is $12 \mathrm{~W}$. For the SWB, the thermal source assumed in Ref. 8 (SWB SARP, Part B, Section 8.3) is $4 \mathrm{~W}$.

There is a large margin between the total heat load calculated in section 3.3.3 $(0.43 \mathrm{~W}$ for the SWB and $0.29 \mathrm{~W}$ for the drum) and the heat load assumed in the reference thermal analyses of the drum (12 W) and the SWB ( $4 \mathrm{~W})$ that resulted in the maximum package temperature with solar insolation used in this report. Thus the maximum solar insolation temperature reported in Ref. 7 and Ref. 8 is bounding for this analysis, and the assumed reaction rate temperatures are conservative. 


\subsection{INTERIOR LAYER PRESSURE AVOIDANCE}

The NucFil filters have a stated flow rate (air) at 1-in. water column (WC) pressure differential of $200 \mathrm{~mL} / \mathrm{min}$. The filters flow rate will be equated to the flow rate through an equivalent cylindrical hole of a known length and known diameter, to show that the filter is equivalent to a hole that gas must pass through. The equivalent hole will then be compared to the holes in the inner layers of the SWB or Drum, to show that inner-layer pressures will not occur.

Density of water:

(25 ${ }^{\circ} \mathrm{C}$, or $77^{\circ} \mathrm{F}$, Ref. 20)

$$
\rho_{\mathrm{h} 2 \mathrm{o}}:=997 \frac{\mathrm{kg}}{\mathrm{m}^{3}}=62.24 \cdot \frac{\mathrm{lb}}{\mathrm{ft}^{3}}
$$

Differential pressure at 1 -in water column:

$$
P_{1 \text { in }}:=\rho_{\mathrm{h} 20} \cdot g \cdot 1 \text { in }=0.036 \cdot p s i
$$

Filter specification flow rate:

(for one filter on the drum, -019)

$$
\operatorname{Spec}_{019}:=200 \frac{\mathrm{mL}}{\min }=3.333 \cdot \frac{\mathrm{cc}}{\mathrm{s}}
$$

The highest flow rate that one filter will see is the single filter on a drum, which was calculated in section 2.3.

$$
\mathrm{T}_{\text {init }_{1}}=145 \cdot{ }^{\circ} \mathrm{F}
$$

The $\mathrm{H}_{2}$ flow rate in the drum at $145^{\circ} \mathrm{F}$ :

(two pigs and one filter on the 55-gallon drum)

$$
\operatorname{Max}_{\text {flow }}:=2 \cdot \text { Vohotal }_{1}=84.4 \cdot \frac{\mathrm{cc}}{\mathrm{hr}}
$$

Note: The hydrogen generation could be greater in the SWB due to possible higher temperatures, but the SWB vent path requires multiple filters. The drum only has one filter, so this will be bounding.

The ratio of the gas volume vented at 1 -in WC to the gas volume produced:

$$
\text { Ratio }_{\text {vent_prod }}:=\frac{\operatorname{Spec}_{019}}{\operatorname{Max}_{\text {flow }}}=142
$$

This ratio shows that even at the highest rate of gas production from both pigs that the drum and SWB filters can easily pass this gas without building any pressure. Finding an equivalent "hole" equal to the filter's flow rate will show that the inner layers will not build pressure.

Poiseuille's law (Ref. 20) relates the volume flow rate for laminar flow through horizontal tubes of diameter $D$ and length $L$ as: 


\section{HNF-43821 Rev. 3}

Poiseuille's law:

$$
\begin{aligned}
& \mathrm{V}_{\mathrm{dot}}=\frac{\Delta \mathrm{P} \cdot \pi \cdot \mathrm{D}_{\mathrm{eq}}{ }^{4}}{128 \cdot \mu \cdot \mathrm{L}_{\mathrm{eq}}} \\
& \mu:=1.825 \times 10^{-5} \frac{\mathrm{kg}}{\mathrm{m} \cdot \mathrm{s}}
\end{aligned}
$$

Dynamic viscosity:

(air at $68^{\circ} \mathrm{F}$, Ref. 20))

The pressure is the 1 -in. WC:

$$
\begin{aligned}
& \Delta \mathrm{P}:=\mathrm{P}_{1 \text { in }}=0.036 \cdot \mathrm{psi} \\
& \mathrm{V}_{\mathrm{dot}}:=\operatorname{Spec}_{019}=3.333 \cdot \frac{\mathrm{cc}}{\mathrm{s}}
\end{aligned}
$$

The flow rate is:

Solving for the diameter:

(as a function of $L$ )

$$
D_{\text {eq }}\left(L_{\text {eq }}\right):=\sqrt[4]{V_{\text {dot }} \cdot \frac{\left(128 \cdot \mu \cdot L_{\text {eq }}\right)}{(\Delta P \cdot \pi)}}
$$

Assume a 3-in. equivalent $L$ :

$$
D_{\text {eq } 33}:=D_{e q}(3 i n)=0.037 \cdot \text { in }
$$

Note that the 3-in. length is just to demonstrate the methodology, actual lengths will be used below.

The area of the 3 -in. equivalent hole:

$$
\mathrm{A}_{\text {eq } 3}:=\frac{1}{4} \pi \cdot \mathrm{D}_{\text {eq_ } 3}{ }^{2}=1.062 \times 10^{-3} \cdot \text { in }^{2}
$$

The methodology of this equivalent "hole" calculation will now be compared to the vent holes in the Super Pig, Piglet, and sample bottle.

\subsection{Super Pig Vent Hole, Flow, and Pressure}

The Super Pig has four vent holes, the holes are half-circles with an $r=0.06$ inch. The half-hole area will be calculated, then the Super Pigs equivalent vent hole size will be determined, and then compared to the size of hole required to vent the Super Pig with a flow rate equal to the filters.

Length of horizontal vent path:

$$
\mathrm{L}_{\mathrm{S}_{\text {p pig_h }}}:=\frac{(12.75-6.27)}{2} \text { in }=3.24 \cdot \text { in }
$$

Diameter of horizontal vent path:

$$
\text { Dia }_{\text {s_pig_h }}:=2 \cdot 0.06 \text { An } \quad \text { Area will be half, as vent is half circle }
$$

Area of horizontal lid vent path: (one vent path)

$$
\text { Area }_{\text {s_pig } \_}:=\frac{\frac{1}{4} \pi \cdot \mathrm{Dia}_{\text {s_pig_h }_{-}}{ }^{2}}{2}=5.655 \times 10^{-3} \cdot \text { in }^{2}
$$

Diameter of a circular cross section vent with the same area as the Super Pig (one vent path)

$$
\operatorname{Dia}_{\text {s_pig_h_eq }_{\_}}:=\sqrt{\frac{\text { Area }_{\text {s_pig_h }}}{\frac{1}{4} \pi}}=0.085 \text {. in }
$$

The equivalent diameter of the Super Pig's vent hole (one) to have the same air flow rate as a NucFil filter at 1 -in. WC pressure (equation from Section 4.0): 
Ratio of actual vent hole (one) to equivalent vent hole:

$$
D_{\text {eq_Superpig }}:=D_{\text {eq }}\left(L_{\text {s_pig_h }}\right)=0.037 \text { in }
$$$$
\text { ratio }_{\text {superpig }}:=\frac{\text { Dia }_{\text {s_pig_h_eq }}}{D_{\text {eq_Superpig }}}=2.3
$$

This shows the Super Pig is adequately vented (assuming just one of the four holes) to avoid pressure in the Super Pig.

Check the Reynolds number to assure the use of Poiseuille's law was correct (properties at room temperature will be conservative).

Average velocity: $\quad$ Vel $_{\text {air }}:=\frac{\mathrm{V}_{\text {dot }}}{\text { (for } 200 \mathrm{~mL} / \mathrm{min} \text { ) }_{\text {s }_{\text {pig }} \mathrm{h}}}=35.97 \cdot \frac{\text { in }}{\mathrm{sec}}$

kinematic viscosity: $\quad v:=1.55 \cdot 10^{-05} \frac{\mathrm{m}^{2}}{\mathrm{sec}}$
$\left(\right.$ at $68{ }^{\circ} \mathrm{F}$ )

Reynolds number: $\quad \mathrm{R}_{\mathrm{e}}:=\frac{\mathrm{Ve}_{\mathrm{air}} \cdot \text { Dia }_{\text {s_pig_h_eq }}}{\mathrm{v}}=127$

Clearly the flow is laminar ( $R_{e}$ less than 2300 ), the use of Poiseuille's law is valid, and the Super Pig will not build pressure.

\subsection{Piglet Vent Hole, Flow, and Pressure}

The Piglet has one vent hole, the hole has a diameter $=0.159$-in. This hole will be compared to the size of hole required to vent the Piglet as well as a NucFil filter could vent air at 1 -in. WC pressure.

Length of lid vent path:

$$
\mathrm{L}_{\text {lid_vent }}:=1.7 \mathrm{sin}+2.09 \mathrm{in}=3.84 \cdot \text { in }
$$

Diameter of lid vent path:

$$
\text { Dia }_{\text {id_vent }}:=0.159 \text { in }
$$

Area of lid vent path:

$$
\text { Area }_{\text {lid_vent }}:=\frac{1}{4} \pi \cdot \text { Dia }_{\text {lid_vent }} 2=0.020 \cdot \text { in }^{2}
$$

The equivalent diameter of the Piglet's vent hole to have the same air flow rate as a NucFil filter at 1-in. WC differential pressure (equation from section 4.0 ):

$$
\begin{aligned}
& D_{\text {eq_Piglet }}:=D_{\text {eq }}\left(L_{\text {lid_vent }}\right)=0.039 \cdot \text { in } \\
& \text { ratio }_{\text {Piglet }}:=\frac{\text { Dia }_{\text {id_vent }}}{D_{\text {eq_Piglet }}}=4.1
\end{aligned}
$$

Ratio of actual vent hole to equivalent vent hole:

This shows the Piglet is adequately vented to avoid pressure in the Piglet.

Check the Reynolds number to assure the use of Poiseuille's law was correct. 


$$
\mathrm{R}_{\text {e.piglet }}:=\frac{\mathrm{Vel}_{\text {air }} \cdot \mathrm{Dia}_{\text {id_vent }}}{v}=238.1
$$

Clearly the flow is laminar ( $R_{e}$ less than 2300 ), the use of Poiseuille's law is valid, and the Piglet will not build pressure.

\subsection{Vented Nalgene® Bottle, Flow, and Pressure}

Drawing H-1-90493 (Ref. 21) shows the lid of the bottle has a 1/16-in. diameter hole. Per a telephone conversation with technical support at Nalgene $\Theta$, the thickness of the lid of the bottle does not exceed 5 $\mathrm{mm}$.

Length of $1 / 16$-in dia. hole in bottle lid:

Diameter of bottle lid hole:

Area of hole in the bottle lid:

$$
\begin{aligned}
& \mathrm{L}_{\text {bottle_lid_hole }}:=5 \mathrm{~mm}=0.197 \cdot \text { in } \\
& \text { Diabottle_lid_hole }:=\frac{1}{16} \mathrm{in}=0.063 \cdot \text { in }
\end{aligned}
$$$$
\text { Area }_{\text {bottle_hole }}:=\frac{1}{4} \pi \cdot \text { Dia } \text { bottle_lid_hole }^{2}=3.068 \times 10^{-3} \cdot \text { in }^{2}
$$

The equivalent diameter of the bottle's vent hole to have the same air flow rate as a NucFil filter at 1-in. WC differential pressure (equation from section 4.0):

$$
\mathrm{D}_{\text {eq_Bottle }}:=\mathrm{D}_{\text {eq }}\left(\mathrm{L}_{\text {bottle_lid_hole }}\right)=0.019 \text { in }
$$

Ratio of actual vent hole to equivalent vent hole:

$$
\text { ratio }_{\text {Bottle }}:=\frac{\text { Dia }_{\text {bottle_lid_hole }}}{D_{\text {eq_Bottle }}}=3.4
$$

This shows the bottle is adequately vented to avoid pressure.

Check the Reynolds number to assure the use of Poiseuille's law was correct.

$$
R_{e . \text { Bottle }}:=\frac{V_{\text {air }} \cdot \text { Dia }}{v}=93.6
$$

Clearly the flow is laminar ( $R_{e}$ less than 2300 ), the use of Poiseuille's law is valid, and the bottle will not build pressure.

\subsection{Vented Bag with a BOP Filter, Flow, and Pressure}

The vented bag that surrounds the bottle has a BOP filter. The filter has a stated flow rate of $4.0 \mathrm{~L} / \mathrm{min}$ of air at 1 -in. water column differential pressure uncorrected to STP conditions, see Appendix 7.5. This flow is about 20 times that of the NucFil filter and will easily vent any pressure coming from the bottle to the pig. No analysis is necessary. 


\subsection{RESULTS AND CONCLUSIONS}

The hydrogen generation rate has been determined for both radiolysis and chemical reaction of uranium metal and water. The hydrogen generation rate was calculated for a sludge volume of $600 \mathrm{~mL}$ in the sample bottle. For a volume of $600 \mathrm{~mL}$ sludge, the maximum reported package temperature with solar insolation was used to show that the percent of hydrogen in the SWB (for two Super Pigs) and in a 55gallon drum (for two Piglets) will be less than $5 \%$.

The thermal heat load (from radioactive decay of the source and daughter isotopes and the exothermic heat of reaction of uranium metal with water) for two sample bottles in either the drum or SWB (shown to I be a maximum of $0.43 \mathrm{~W}$ ) is less than the assumed heat load used in either the SWB or Drum SARP to establish the maximum solar package temperature. With the resulting bounding temperature, the reaction rates in this report are conservative.

The following constraints are required:

For the SWB:

1. A minimum of two NucFil-019 filters or equivalent $\left(\mathrm{H}_{2}\right.$ diffusivity of $2.4 \mathrm{E}-05 \mathrm{Mol} / \mathrm{sec} / \mathrm{mol}$ fraction or greater for each filter) are required, or a minimum of three NucFil-013 filters or equivalent $\left(\mathrm{H}_{2}\right.$ diffusivity of $1.1 \mathrm{E}-05 \mathrm{Mol} / \mathrm{sec} / \mathrm{mol}$ fraction or greater for each filter) are required.

2. Two Super Pigs, each containing $600 \mathrm{~mL}$ of sludge, are allowed in the SWB.

3. The SWB is known (Ref. 8) to reach container temperatures no greater than $157^{\circ} \mathrm{F}$ due to solar insolation. The $\mathrm{H}_{2}$ gas generated at $157^{\circ} \mathrm{F}$ was calculated and the volume percent of $\mathrm{H}_{2}$ is $2.8 \%$ with two -019 filters, and $4.1 \%$ for three -013 filters.

4. This configuration requires no protection from solar insolation and may be transported in ambient conditions up to $115^{\circ} \mathrm{F}$.

For the 55 -gallon drum with a single $3 / 4$-in. filter ( -019 or equivalent):

1. One NucFil-019 or equivalent $\left(\mathrm{H}_{2}\right.$ diffusivity of $2.4 \mathrm{E}-05 \mathrm{Mol} / \mathrm{sec} / \mathrm{mol}$ fraction or greater) filter is required.

2. Two Piglets, each containing $600 \mathrm{~mL}$ of sludge, are allowed in the drum.

3. 55-gallon drums have been shown (Ref. 7) to reach no greater than $145^{\circ} \mathrm{F}$ due to solar insolation. The $\mathrm{H}_{2}$ gas generated at $145^{\circ} \mathrm{F}$ was calculated and the volume percent of $\mathrm{H}_{2}$ is $3.5 \%$ with one -019 filter.

4. This configuration requires no protection from solar insolation and may be transported in ambient conditions up to $115^{\circ} \mathrm{F}$.

Using a method of equivalent "holes," e.g. a hole with the same flow rate as the SWB or drum filter, it has been shown that each layer (bottle, bag and pig) in the containment boundary is designed with a vent path that exceeds that of the SWB or drum fiter. No internal pressurization will occur. 


\subsection{REFERENCES}

1. Super Pig drawings, H-1-90367, H-1-90368, H-1-90369, H-1-90370, and H-1-90371.

2. Drawing H-1-80792, Rev. 0, Shipping Container Sludge Sample Bottle Assy \& Details (Vented Piglet).

3. Drawing H-1-89099, Rev. 1, Shipping Container Sludge Sample Bottle Vented Lid Assembly (Vented Piglet lid).

4. PRC-STP-CN-O-00222, Rev. 0, 2010, Settler Sludge Sample Shipment Container Evaluation, L. A. Nelsen, CH2M HILL Plateau Remediation Company, Richland, WA.

5. Drawings 165-F-001-W1, W2, W3, and W4 Rev. V, Standard Waste Box Assembly, Washington TRU Solutions LLC, Waste Isolation Pilot Plant, Carlsbad, NM.

6. West, R. C., 1980, CRC Handbook of Chemistry and Physics, $61^{\text {st }}$ Edition, CRC Press, Inc., Boca Raton, FL.

7. HNF-2209, Rev. 1B, 2006, Safety Analysis Report for Packaging (Onsite) Steel Drum, P. G. Johnson, Fluor Hanford, Inc., Richland, WA.

8. HNF-SD-TP-SARP-004, Rev. 2, 2005, Safety Analysis Report for Packaging (Onsite) Standard Waste Box, W. L. Willis, Fluor Hanford, Inc., Richland, WA.

9. Delegard, C.H. and A.J. Schmidt, 2010, Enthalpies and Free Energies of Reaction for Uranium Phases and Metals of Interest to Transportation of K Basin Sludge, 46497-RPT14, Pacific Northwest National Laboratory, Richland, WA.

10. HNF-41051, Rev 5, 2009, Preliminary STP Container and Settler Sludge Process System Description and Material Balance, M. E. Johnson and T. K. Dhaliwal, CH2M HILL Plateau Remediation Company, Richland, WA.

11. HNF-SD-SNF-TI-015, Volume 2, Rev. 14A, 2009, Spent Nuclear Fuel Project Technical Databook, Vol. 2, Sludge, A. J. Schmidt, CH2M HILL Plateau Remediation Company, Richland, WA.

12. PNNL-17815, Rev.1, 2009, Uranium Metal Reaction Behavior in Water, Sludge, and Grout Matrices, C. H. Delegard and A. J. Schmidt, Pacific Northwest National Laboratory, Richland, WA.

13. SNF-7765, Rev 3D, 2009, Supporting Basis for SNF Project Technical Databook, A.J. Schmidt and R. A. Sexton, CH2M HILL Plateau Remediation Company, Richland, WA.

14. HNF-SD-SNF-TI-009, Vol. 2, Rev. 4, 2001, (Table 4-1), 105-K Basin Material Design Basis Feed Description for Spent Nuclear Fuel Project Facilities, Volume 2, Sludge, K. L. Pearce, Fluor Hanford, Inc., Richland, WA.

15. Cussler, E. L., 2009, Diffusion, Mass Transfer in Fluid Systems, 3rd Edition, Cambridge University Press, New York, NY.

16. Perry's Chemical Engineers' Handbook (Sixth Edition, Table 3-318, page 3-256, reference to the International Critical Tables), McGraw-Hill Book Company, New York, NY.

17. Drawing CQ5540-FLUO001, Rev. A4, (typical), 55 Gallon Open Head Drum, Skolnik Ind., Inc., Chicago, IL. 


\section{HNF-43821 Rev. 3}

18. Sketch No. KBC-SK-437, Rev. 1, Contamination Control Bag, CHPRC Engineering Sketch.

19. HNF-SD-TP-SARP-017, Rev. 3-G, 2008, Safety Analysis Report for Packaging (Onsite) Multi-canister Overpack Cask, T. S. Vail, Fluor Hanford, Inc., Richland, WA.

20. Cengel, Y. A. and J. M. Cimbala, 2010, Fluid Mechanics, Fundamentals and Applications, 2nd Edition, McGraw Hill Higher Education, New York, NY.

21. Drawing H-1-90493, Rev. 2, K West Basin Sludge Sampler Cart Assembly.

22. Drawing H-1-91238, Rev. 0, Transportation Drum Shielded Container Rack. 


\subsection{APPENIDIX}

7.1 NucFil Product Specification Data Sheets (-013, and -019)

$9 / 02$

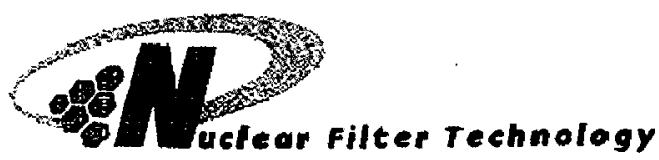

Page 1 of 1

741 Corporate Circle, Suite R Golden, colorado 80401

\section{Product Specification Data Sheet}

Model: NucFilB 013

Specification \#: NFT-013

Engineering

Drawing \#: 05130000
Date: $12 / 22 / 2003$

Fovision: 5

Usage:

Control VOC release and ventilation of hydrogen gas generated in 55 gal drums, containers, and Standard Waste Boxes containing TRU, Low Level, Hazardous or Mixed Wastes. Installed into $3 / 4^{" \prime}$ flange of newly generated drum lids with 10 -foot pounds of torque. Torque to 15-foot pounds on drums weighing more than $900 \mathrm{lbs}$.

Performance Characteristica:

Particle Removal Efficiency: Tested at greater than $99.97 \%$ of $0.3 \mu 100.5 \mu$ poly-

Resistance to Flow: dispersed (DOP) aerosol.

Hydrogen Diffusivity:

Less than 1.0"W.C. DP $200 \mathrm{ml} / \mathrm{min}$

Notes:

1,1 E-0.5 Mol/Sec/mol Frac

Physical Characteristics:

Filter Media:

Carbon-bonded-Carbon

Sizo:

Overall Helght: $1.10^{*}$

Diameter: $1.64 "$

Thread Type $3 / 4^{n}-14$ NPS

Profille: .358"

Matertal of Construction:

Type 304 Stainless steel

Type of Installation:

Threaded into $3 / 4$ " pipe thread bung typical

Type of Seal:

Neoprene gasket .125" thick, 50-70 durometer

In conformance to the following Standerds or Specifications:

ASME-NQA-1, DOT 7A, Trampac Rev.19 Appendix 2.5

Identiflcation markinos:

(All hems with be marked wim the following intomation at a minimum)

Model Number: NucFik013

Date of Manufacture: (mm/yy)

Unique Serial Number: 
HNF-43821 Rev. 3

9102

741 Corporote cirsle, suite q Golden, Colorado 00401

\section{Product Specification Data Sheet}

Model: NucFil ${ }^{\circ} 019$

Date: 03/18/04

Specification \#: NFT-019

Revision: 2

Engineering

Drawing \#: 05190000

Usage:

Advanced desion for Control VOC release and ventilation of hydrogen gas generated in 55-gallon drums, overpack drums, and Standard Waste Boxes containing TRU. Low Level, Hazardous or Mixed Wastes. Installed into $3 / 4^{n}$ flange of newly generaled waste drum lids with 10 -foot pounds

torque. Maximum hydrogen permeability without loss of integrity.

Partormance Characientstica:

Particle Removal Efficiency: Tested at greater than $99.97 \%$ of $0.3 \mu$ to $0.5 \mu$ poly-

dispersed (DOP) aerosol.

Less than 1.0" W.C. OP $200 \mathrm{mi} / \mathrm{min}$

Hydrogen Diffusivity: $\quad 2.4 \mathrm{E}-05 \mathrm{Mol}$ sec/mol fraction

Notes:

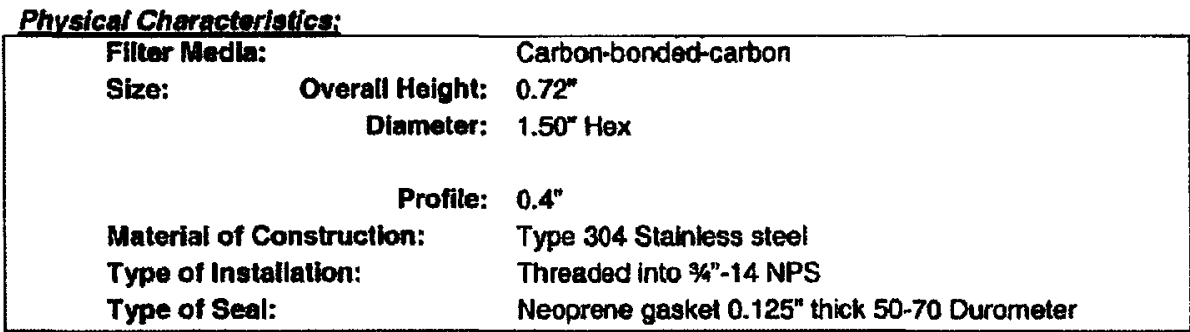

In conformance to the following Standards or Specifications: ASME-NQA-1

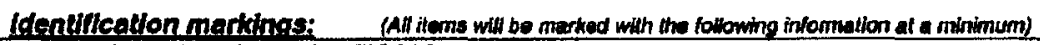
Model Number: NucFile019

Date of Manulacture: (MM/YY)

Unique Serial Number:

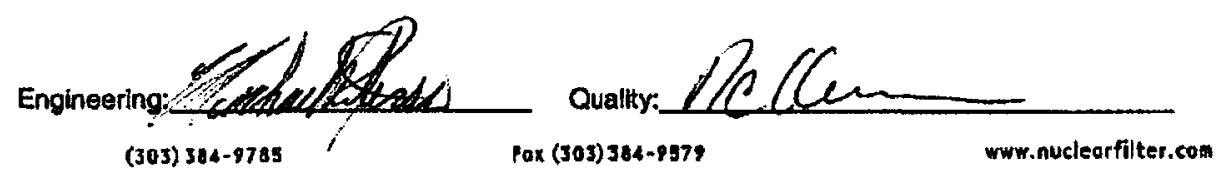


HNF-43821 Rev. 3

7.2 Piglets in the 55-Gallon Drum (Ref. 22)

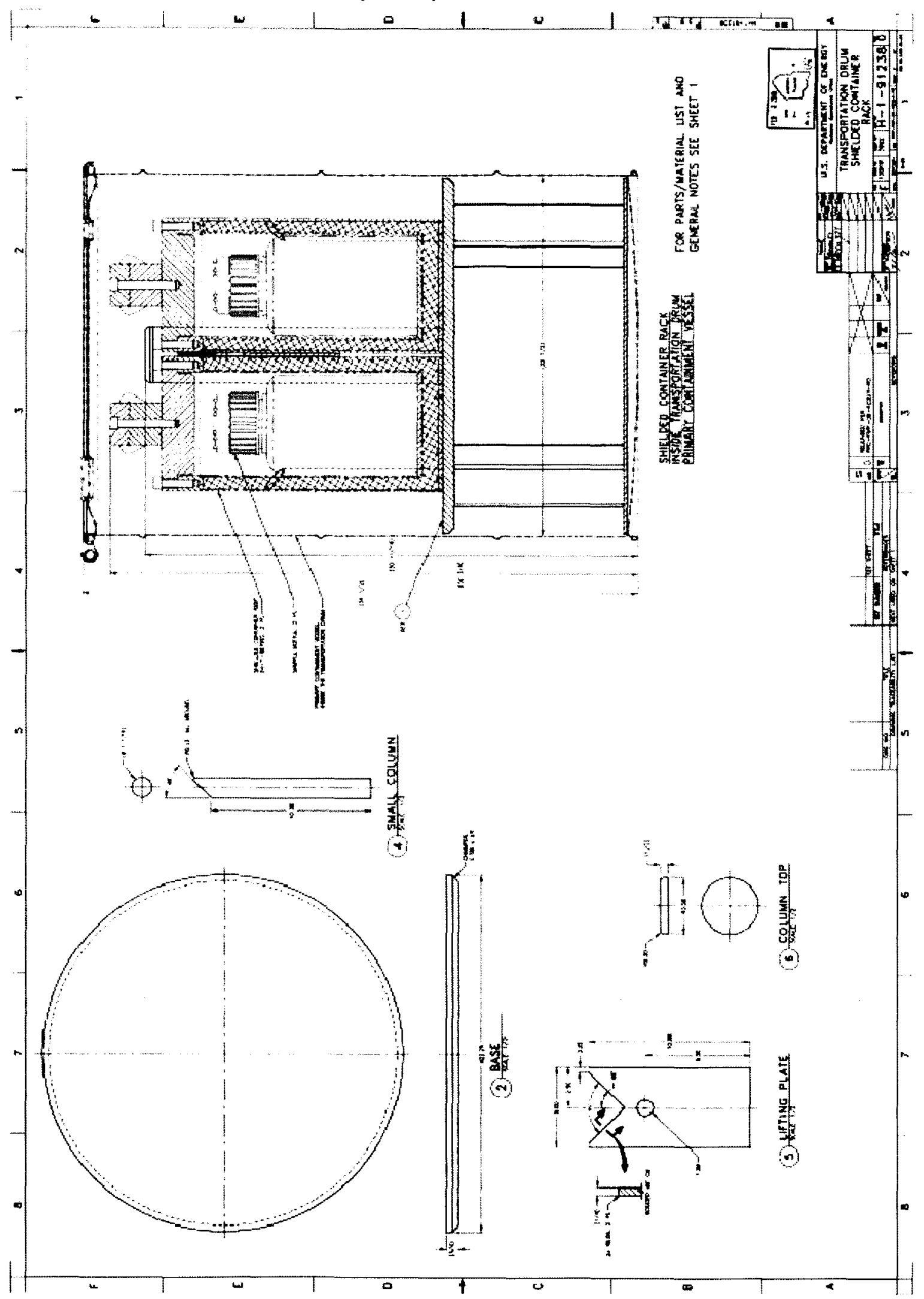


7.3 Piglets Vented Lid (Ref. 3)

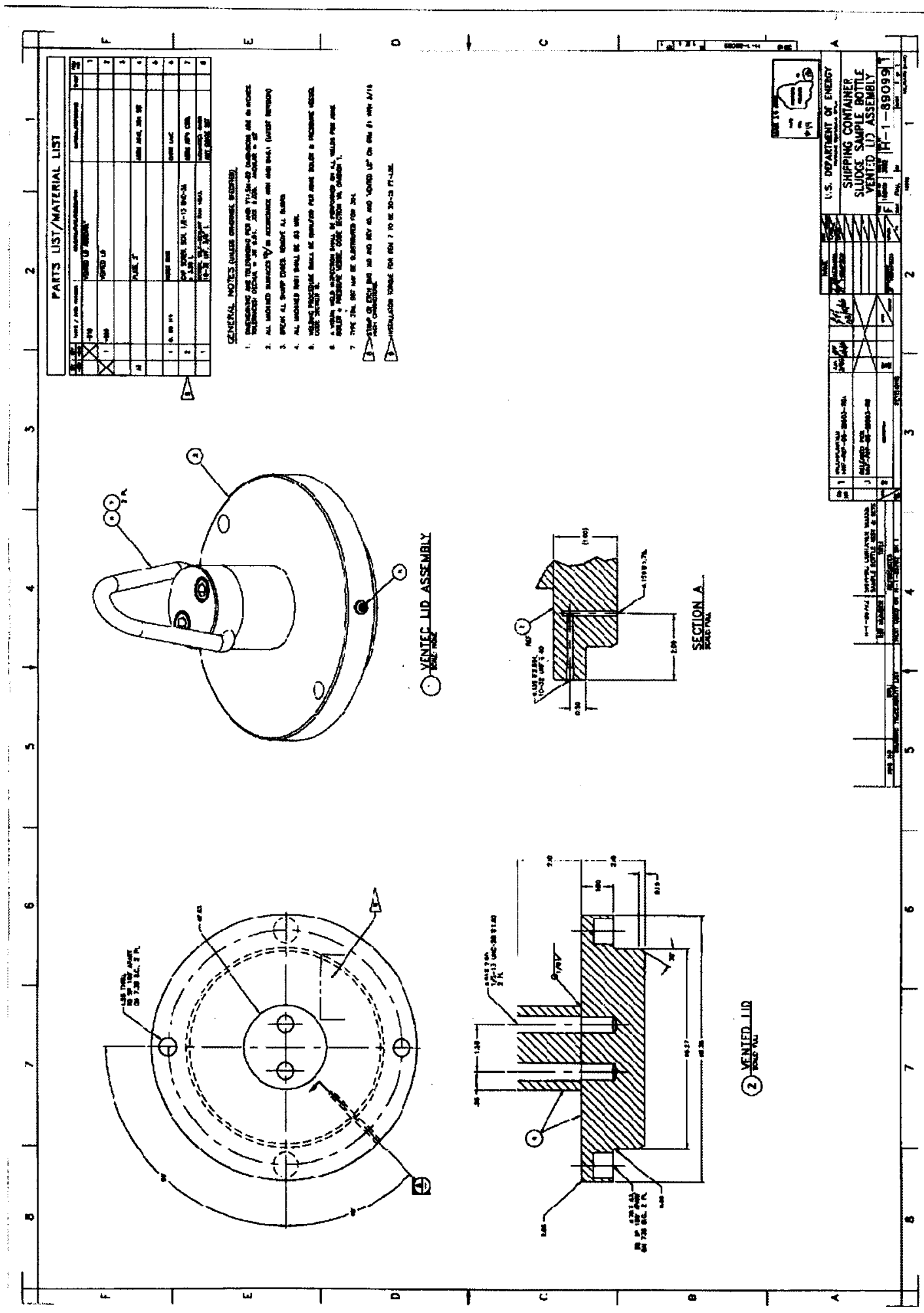




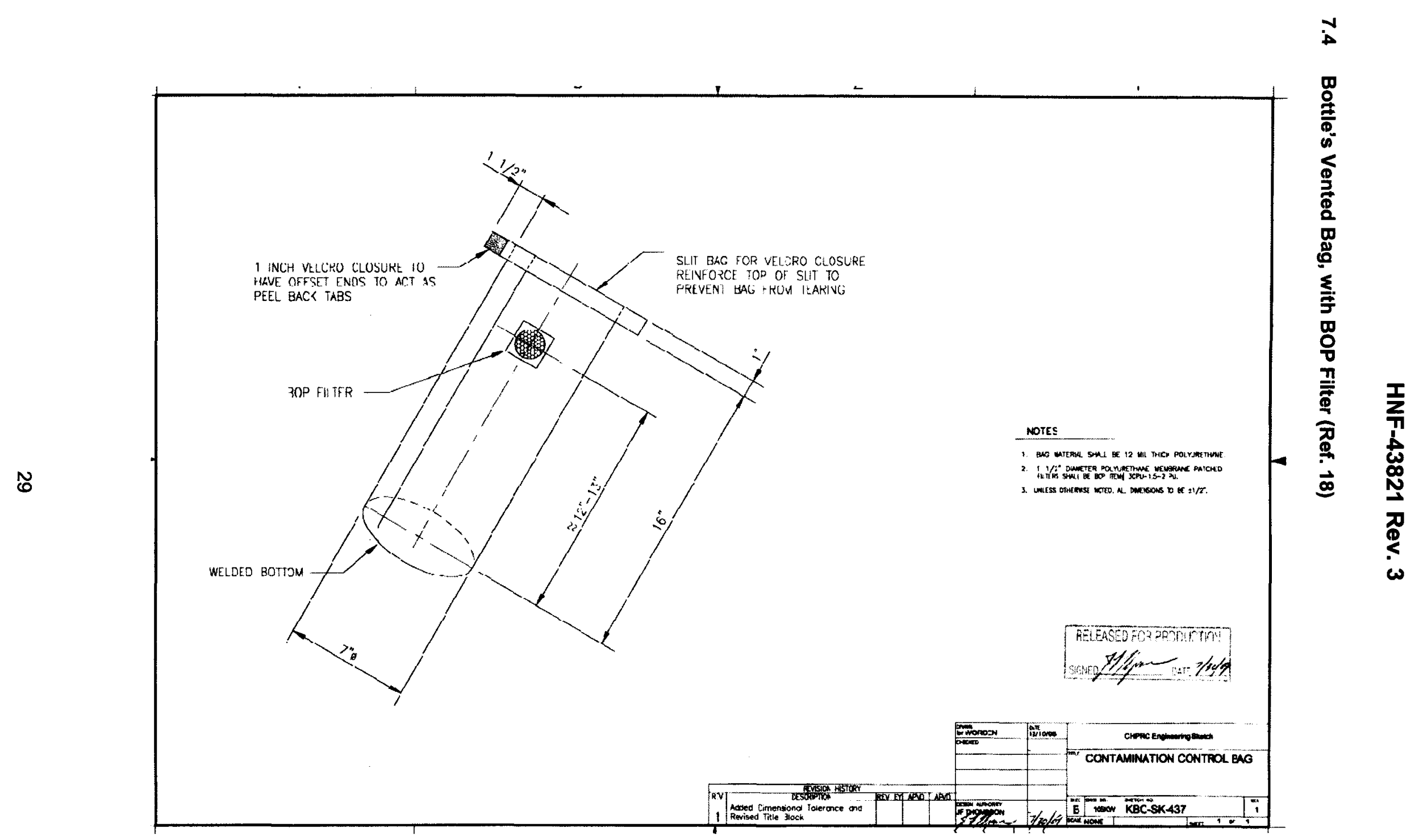




\subsection{BOP Filter Sample Test Report (2 pages total)}

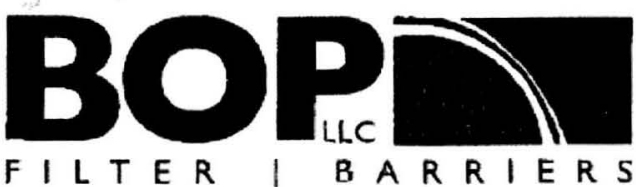

October 9, 2008

Mr. Joe Lechmann

LANCS Industries Inc. 12704 NE 124th St. \#36

Kirkland. WA 98034

Subject: Test Report for Filter Diffusivity, Efficiency and Flow Rate of BOP 3CPU-1.5". 2PU Filters for LANC's PO \#19127

The 3CPU-1.5"-2PU filters manufactured by BOP Filter/Barriers LLC (BOP) and further identified by serial numbers recorded on the filters have been tested for flow and efficiency as described in this report. Separate tests performed at Jacksonville University tested the diffusivity of this filter design. All filters provided meet the requirements as stated below.

- Filters are manufactured by BOP and the filtering material is made from split (melt blown) polypropylene fibers.

- The flow rate of these filters is approximately $4.0 \mathrm{~L} / \mathrm{min}$ of air at $1^{\prime \prime}$ of water column differential pressure uncorrected to STP conditions. This flow rate is. approximately 100 times the required flow rate of $35 \mathrm{~mL} / \mathrm{min}$ of air at standard temperature and pressure with a 1 " water column pressure differential.

- The hydrogen diffusivity of this filter design has been tested at Jacksonville University and is $1.12=0.04 \times 10^{-4} \mathrm{~mole} / \mathrm{second} / \mathrm{mole}$ fraction that is approximately 10 times the requested value of $1.075 \times 10^{-5} \mathrm{~mole} / \mathrm{second} / \mathrm{mole}$ fraction. A copy of this report is available upon request from BOP Filter/Barriers LLC.

- Filter efficiency is tested to be $99.98 \%$ or higher with a monodispersed DOP aerosol of 0.3 micron particles in a penetrometer test. This test exceeds the requirements for filter efficiency of $99.97 \%$ with particles of 0.3 to 0.5 microns of DOP.

- The filters are welded to two 1.5" ID x 4.0" OD discs of 6 mil yellow polyester polyurethane to facilitate mourting into similar plastic membranes.

- Background

This test report documents the methodology for testing of BOP's 3CPU-1.5"-2PU filters to ensure they meet their specified design criteria and that they perform to, or exceed, the

www.bopfilters.com 
requirements for a HDBF5X filter specification in Table 2.5-1 of Appendix 2.5 of the WIPP TRAMPAC document. The filter supplied has twice the diffusivity required for the HDBFSX fliter.

Test Methodology

The system used for testing is a customized TDA-100, monodispersed aerosol penetrometer, produced by Air Techniques Inc. The test is performed in accordence with ASTM D 2986-71, Standard Practice for Evaluation of Air Assay Media by the Monodisperse DOP (Dioctyl Phthainte) Smoke Test. BOP mainteins a Test Program in accordance with SNT-TC-1A that is administered by our ASNT NDT Level III Certified Tester, Paul Pinson.

Test Procedure

BOP's detailed written procecture utilizes calibrated instruments for all data that is reported in our test reports. A constant flow rate of $4.0 \mathrm{~L} / \mathrm{min}$ is set as the controlling parameter for these tests. This is approximately equivalent to $1^{n}$ of water column differential pressure.

\section{Test Data}

Original test data is recorded in BOP's hardbound test data logbooks that are retained as Quality Records in our files. Data are recorded in chronological order by date and by the unique serial number on cach filter. Data recorded includes the differential pressure from the delta pressure meter, flow from the rotometer setting and penetration from our penetration meter.

\section{CPU-1.5-2PU Filters Delivery Schedule}

\begin{tabular}{|c|c|c|c|}
\hline $\begin{array}{c}\text { Dere Shipped to LANCS Inciustries } \\
\text { Inc }\end{array}$ & $\begin{array}{c}\text { Quantity } \\
\text { Shtpped }\end{array}$ & Flher Serial Numbers & Test Date \\
\hline $10 / 02 / 08$ & 100 & 75101 to 75200 & $8 / 22 / 08$ \\
\hline $10 / 02 / 08$ & 400 & 75201 to 75600 & $8 / 27 / 08$ \\
\hline $10 / 09 / 08$ & 100 & 75601 to 75700 & $10 / 07 / 08$ \\
\hline $10 / 09 / 08$ & 50 & 75701 to 75750 & $1009 / 08$ \\
\hline
\end{tabular}

I certify that the $\mathrm{S} / \mathrm{N}$ filters identified above have been tested as described in this report and that they have a minimym efficiency of $99.98 \%$ with a 0.3 micron DOP Smoke Test.

Certitied by:

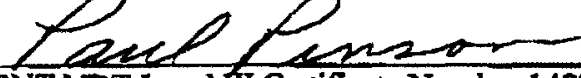

Paul Pinson ASNT NDT Level III Certificate Number 148298

Date: $10 / 09 / 2008$ 
HNF-43821 Rev. 3

\subsection{Sample Bottle (2 pages total)}

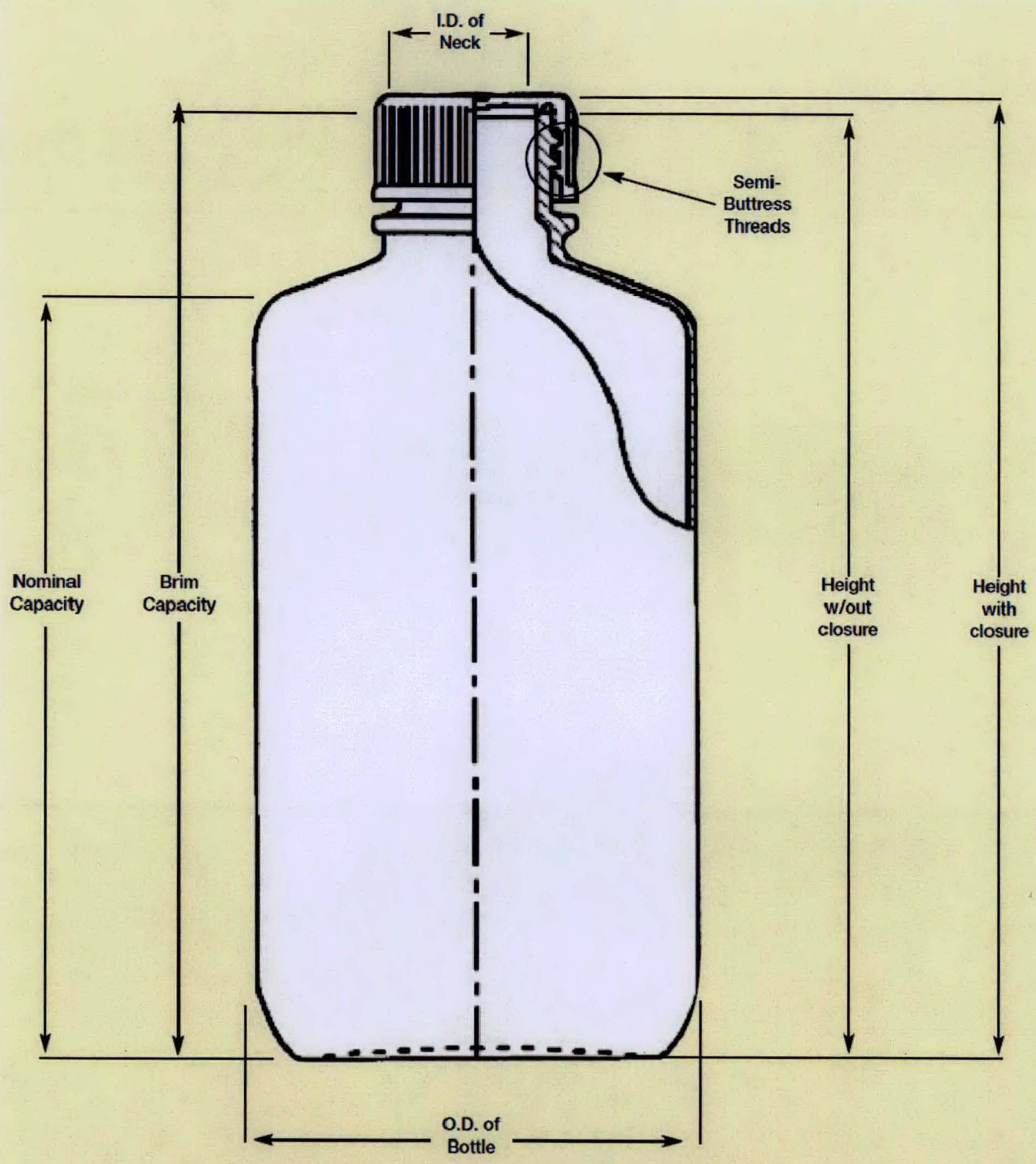




\begin{tabular}{|c|c|c|c|c|c|c|c|c|}
\hline $\begin{array}{c}\text { Nominal } \\
\text { Capacity }\end{array}$ & Description & $\begin{array}{c}\text { Catalog } \\
\text { Number }\end{array}$ & $\begin{array}{c}\text { Approx. Brim } \\
\text { Cap, } \mathrm{ml}\end{array}$ & Material & $\begin{array}{c}\text { I.D. Neck, } \\
\text { mmin. }\end{array}$ & $\begin{array}{c}\text { Hgt. w/ Closure, } \\
\text { mm/in. }\end{array}$ & $\begin{array}{c}\text { Hgt. W/o Closure, } \\
\text { mm/in. }\end{array}$ & $\begin{array}{c}\text { O.D. Bottle, } \\
\text { mm/in. }\end{array}$ \\
\hline $4 \mathrm{~L}(1$ gal) & $\begin{array}{c}\text { Bolle, } \\
\text { Heavy Duty }\end{array}$ & $\begin{array}{c}2126- \\
4000\end{array}$ & 4,100 & PP & $65 / 29 / 16$ & $338 / 135 / 16$ & $327 / 127 / 8$ & $155 / 61 / 6$ \\
\hline
\end{tabular}

From Bottle Specifications in Thermo Scientific Nalgene Plastics Technical Guide at the NALGENE $\mathbb{0}$ website, www.NALGENElabware.com. 


\section{HNF-43821 Rev. 3}

\subsection{Sample Bottle Source Term and $\mathrm{H}_{2}$ Generation from Radiolysis}

Radcalc 4.1 was used for this report. The sample bottle source term was determined as follows:

1) The sludge source data is taken from Ref. 9, Table 2-2a Sludge Radionuclide Inventories (Decayed to 5-31-1998). The data was decayed to 1/1/2010, including January 1 , the duration is 4234 days. The data was also decayed a nominal 15 days. The worst case $\mathrm{H}_{2}$ generation resulting from these two results was used in this report.

2) The volume in the $4.1 \mathrm{~L}$ bottle that is not sludge is conservatively assumed to be $\mathrm{KE}$ canister water, from Ref. 12, Table 4-1 Nominal Inventory for $K$ Basin Water Associated with Sludge, i.e., ${ }^{137} \mathrm{Cs}$ concentration an order of magnitude greater than that in KW canister water. The "nominal" water source term from this table is used for the design basis inventory.

An Excel spreadsheet was used to determine the specific inventory for an arbitrary volume of sludge with the remaining volume water, as discussed above. The results from the spreadsheet were used as inputs for Radcalc 4.1 which resulted in the $\mathrm{H}_{2}$ generation results from radiolysis used in this report.

The source inventory for $600 \mathrm{~mL}$ of sludge (with the remaining volume water) is shown below in Table 7.7.1. The Table 7.7.1 column titled Design Total is the combinations of the water and Design Basis sludge. It is these totals that are input into Radcalc 4.1 .

Section 7.7.1 and 7.7.2 contains the Design Basis Radcalc 4.1 output for the two decay times.

The Radcalc 4.1 program was obtained from https://www.radcalc.energy.gov/dnnradweb, and the author and checker of this report are authorized and registered Radcalc users. As required by the Radcalc authorization instructions, the "download" menu was checked for Problem Report/Change Request (PR/CR) information. Two PR/CR reports were found as of the date of this report: PR/CR-68 and PR/CR64. Both PR/CR's were read and found to not impact the Radcalc results used in this report. The Radcalc installation verification report, showing "Verification Status: Passed" is on file in the Transportation Safety organization. 
Table 7.7.1 Source Inventory for $600 \mathrm{~mL}$ Sludge (Radcalc 4.1 Input)

\begin{tabular}{|c|c|c|c|}
\hline & Design & & Design \\
\hline & Sludge & Water & Total \\
\hline sotope & $\mathrm{Ci}$ & $\mathrm{Ci}$ & $\mathrm{Ci}$ \\
\hline Co-60 & $6.30 \mathrm{E}-03$ & 5.50E-05 & $35 E-03$ \\
\hline Sr-90 & $2.40 E+00$ & 5.81E-02 & $46 E+00$ \\
\hline-90 & $2.40 \mathrm{E}+00$ & 5.81E-02 & $2.46 E+00$ \\
\hline Tc-99 & $9.30 \mathrm{E}-04$ & & $9.30 \mathrm{E}-04$ \\
\hline$s-134$ & $0.00 E+00$ & $1.49 E-04$ & $1.49 E-04$ \\
\hline s-137 & $1.44 E+00$ & 4.62E-02 & $1.49 E+00$ \\
\hline$a-137 m$ & $1.36 \mathrm{E}+00$ & 4.37E-02 & $1.40 \mathrm{E}+00$ \\
\hline $\mathrm{u}-152$ & $0.00 E+00$ & $2.06 \mathrm{E}-04$ & 2.06E-04 \\
\hline d-154 & $1.91 \mathrm{E}-02$ & $1.44 \mathrm{E}-04$ & 1.93E-02 \\
\hline Eu-155 & $9.06 E-03$ & $5.85 E-04$ & $9.64 E-03$ \\
\hline U-234 & 3.01E-04 & & $3.01 E-04$ \\
\hline U-235 & 1.03E-05 & & $3 E-05$ \\
\hline U-236 & $3.40 \mathrm{E}-05$ & & $E-05$ \\
\hline U-238 & $2.10 \mathrm{E}-04$ & & 2.10E-04 \\
\hline Np-237 & $1.32 \mathrm{E}-05$ & $3.22 \mathrm{E}-06$ & 1.64E-05 \\
\hline Pu-238 & 2.35E-02 & 7.32E-06 & 2.35E-02 \\
\hline Pu-239 & 8.40E-02 & 7.32E-06 & 8.40E-02 \\
\hline $\mathrm{Pu}-240$ & $4.59 \mathrm{E}-02$ & 7.32E-06 & 4.59E-02 \\
\hline Pu-241 & $2.63 E+00$ & & $2.63 E+00$ \\
\hline Pu-242 & 2.07E-05 & & 2.07E-05 \\
\hline Am-241 & 1.12E-01 & $5.29 \mathrm{E}-04$ & $1.13 E-01$ \\
\hline & 0 & & +0 \\
\hline
\end{tabular}

0.6-L 50/50 KE/KW Canister Sludge, Table 2-2a, HNF-41051 Rev. 5 3.5-L KE Canister Water, Table 4-1, HNF-SD-TI-009, Vol 2, Rev 4

4.1-L Size of the poly bottle for sludge 
HNF-43821 Rev. 3

\subsection{1 $600 \mathrm{~mL}$ Design Basis Radcalc 4.1 Results Decayed to 1/1/2010}

Radcalc 4.1: D:IHanfordI2009UH2GENIrad filesloriginal_0_6L_Design_4234day_rev.rad

Performed By: Checked By:

$\operatorname{LC} 3 / 2\} / 1^{\circ}$

Don Riley Alvia Bridges aEB $3 / 24 / 10$

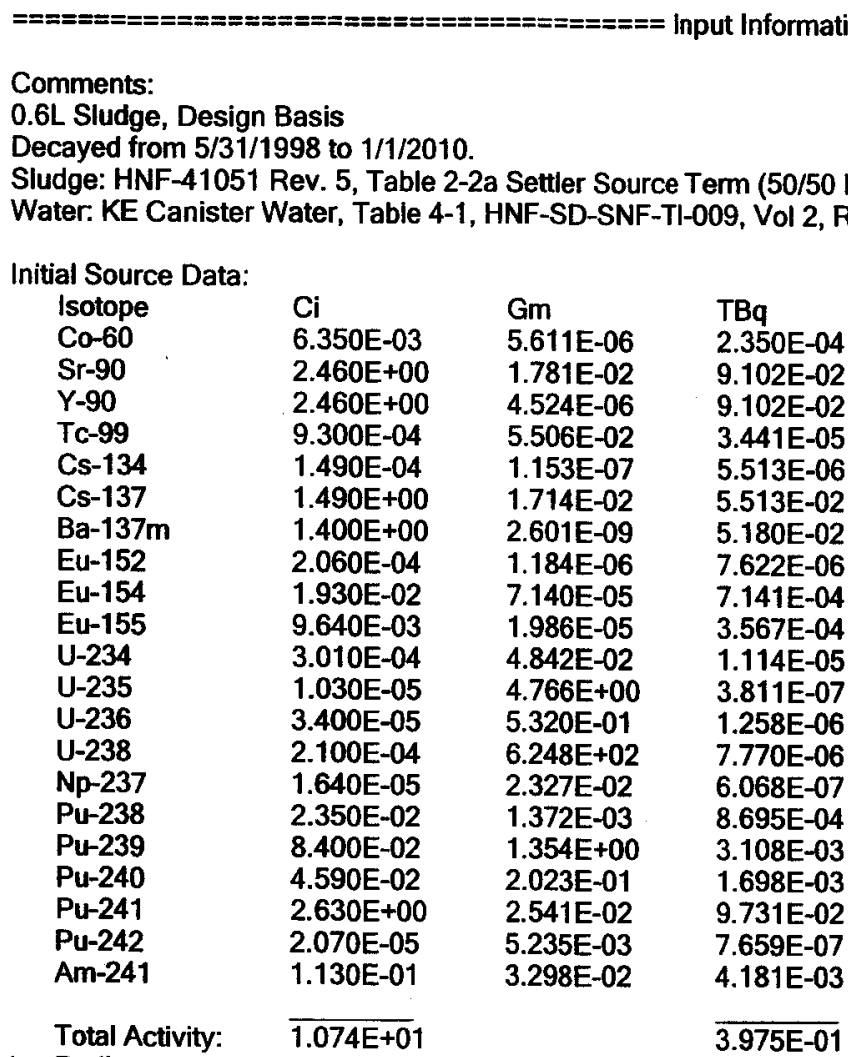

* Radionuclides with an A1/A2 fraction of less than 0.001 will not be shown in the output.

Container Data:

Container Void Volume: $\quad 0.0542 \quad \mathrm{~m}^{\wedge} 3$

Container Mass:

Mass of solid beryllium, lead, graphite, and hydrogenous material enriched with deuterium:

Gross Mass:

$\begin{array}{ll}0.0542 & \mathrm{~m}^{\wedge} 3 \\ 5806 & \mathrm{~kg} \\ 0 & \mathrm{~kg} \\ \mathbf{5 8 1 6} & \mathrm{kg}\end{array}$

Waste Data:

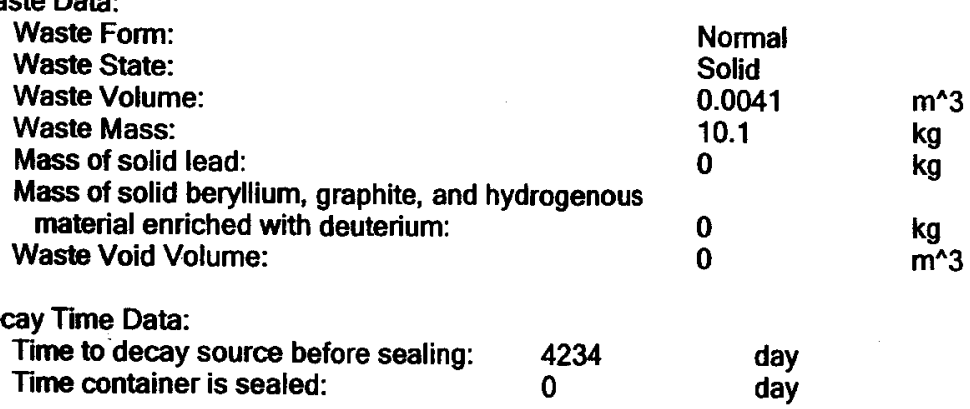

Gamma Absorption Model: Gamma Abs Model:

$100 \%$ Gamma Absorption 
HNF-43821 Rev. 3

$\begin{array}{lll}\begin{array}{l}\text { G Value Data: } \\ \text { G Alpha }\end{array} \quad \text { G Beta } & \text { G Gamma } \\ \begin{array}{l}0.24 \\ \text { G values entered by the user. }\end{array} & \end{array}$

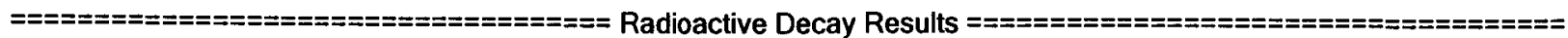

Decayed Source:

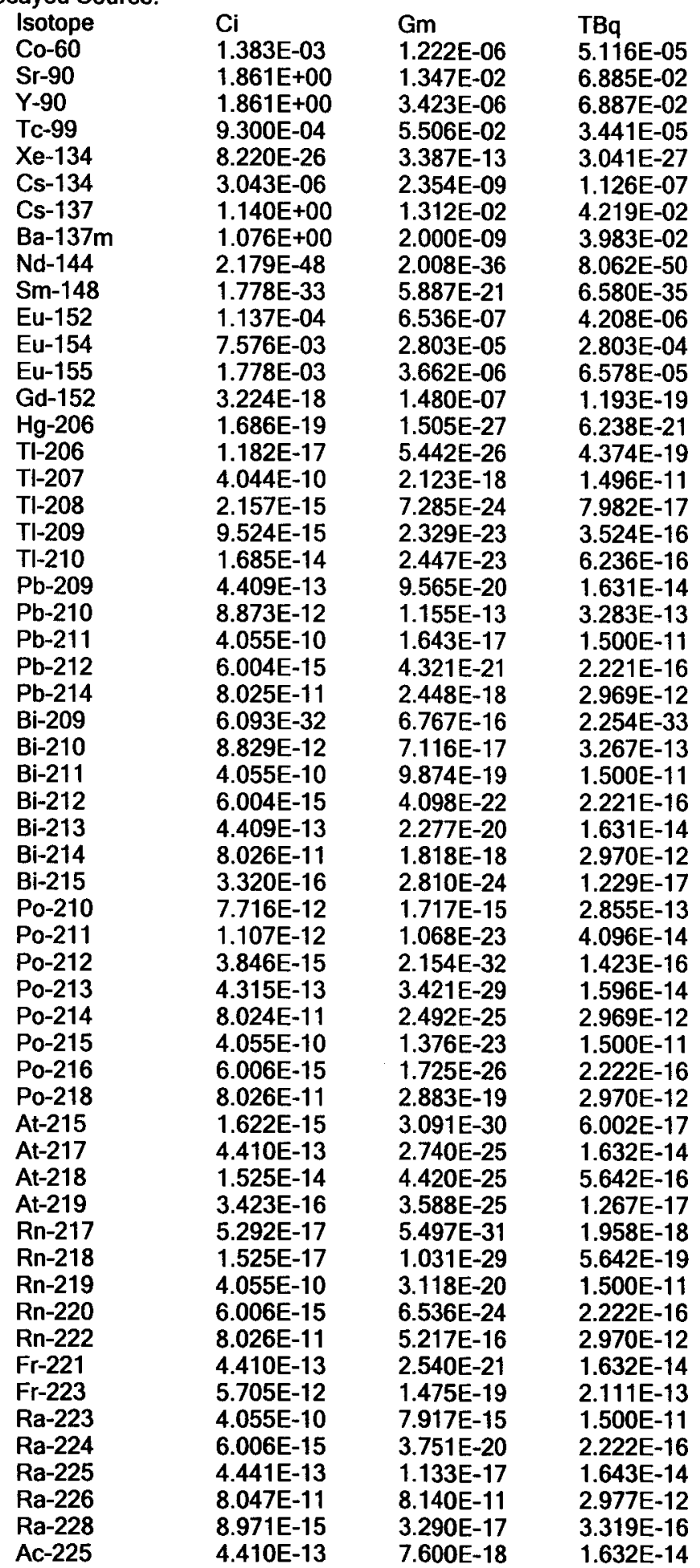


HNF-43821 Rev. 3

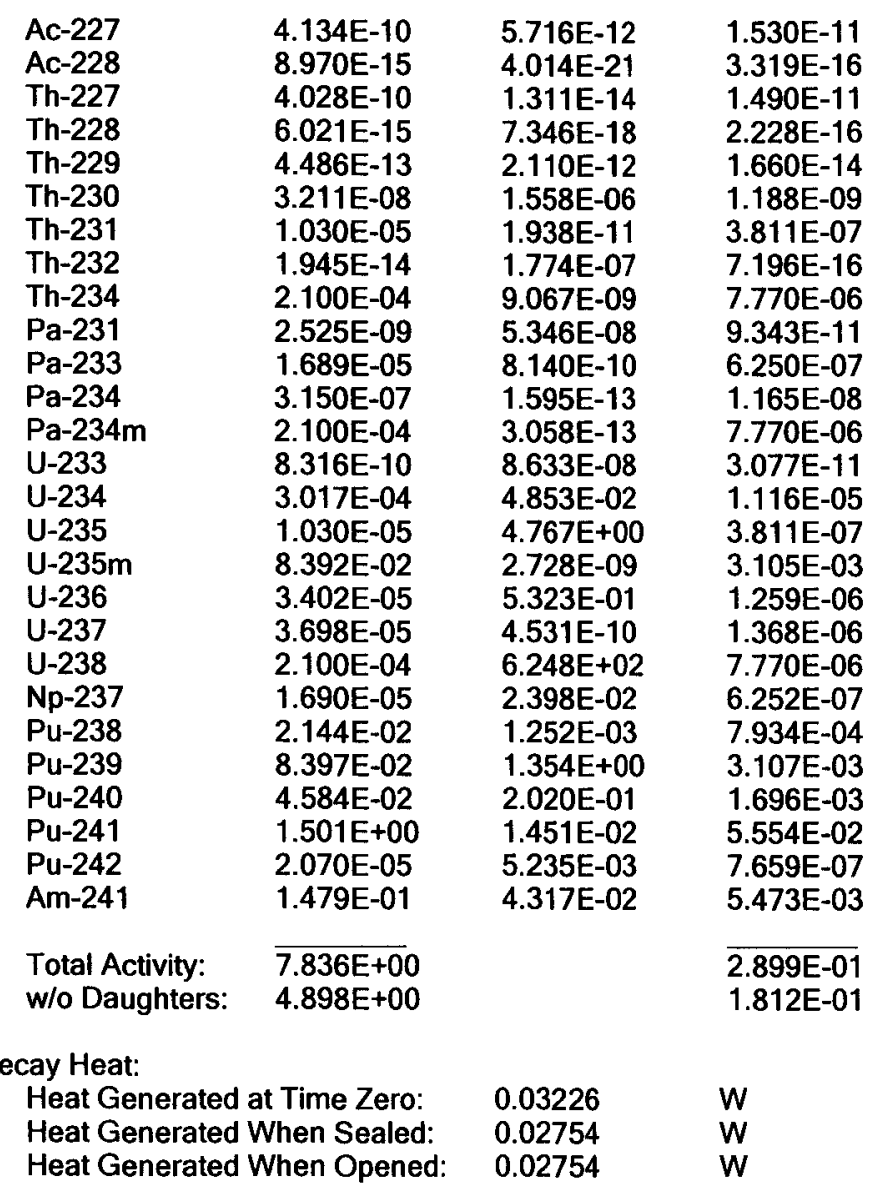

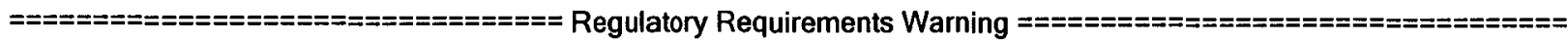

Radcalc utilizes numerically based criteria to classify packages against the regulations. Many regulations also include subjective criteria that Radcalc does not consider. The user must check to ensure that all requirements in the regulations are met.

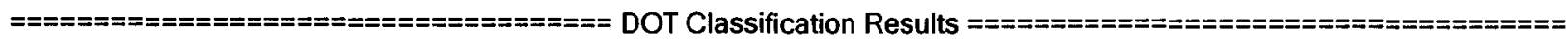

* DOT classification calculations are made at the end of the user-specified decay time.

Radioactive Determination:

Radioactive:

ACEM Limit Fraction: $\quad 1671000$

ACEMs

(ACEMs and ALECs > 1.0)

ALEC Limit Fraction:

$14610000 \quad$ ALECs

(Number of ACEMs)

* This package is not exempt from 49 CFR Subchapter C.

(Number of ALECs)

Effective A2s for Mixture:

$1.455 \mathrm{E}+10 \quad \mathrm{~Bq}$

Type Determination:

Type:

A2 Limit Fraction:

B

12.45

A2s (Number of A2s)

Limited Quantity Determination:

Limited Quantity:

Activity:

No

12.45
7.836

0.2899

A2

(Solid, activity $>0.001 \mathrm{~A} 2$ )

Fissile:

Yes

Fissile Excepted:

Yes (b)

TBq

LSA Determination: 
HNF-43821 Rev. 3

LSA-I:

LSA-II:

LSA-III:

Specific Activity:

HRCQ Determination: HRCQ:

A2 Limit Fraction:

Activity:

Fissile Determination:

Fissile:

No

No

Yes

0.001233

0.0007759

A2/gm

Ci/gm

No

12.45

7.836

0.2899

A2s

$\mathrm{Ci}$

TBq

Yes

Yes (b)

6.135

gm

0

$5806000 \quad \mathrm{gm}$

$\begin{array}{ll}0 & \mathrm{gm}\end{array}$

Container Mass:

Waste beryllium, graphite, and hydrogenous material enriched with deuterium:

Waste Mass:

Solid Non-Fissile Mass:

Total Uranium Mass:

U-233 Mass:

U-235 Mass:

Uranium Enrichment:

Total Plutonium Mass:

Pu-239 Mass:

Pu-241 Mass:

\section{0}

10100

5816000

630.1

8.633E-08

4.767

0.7564

1.577

1.354

0.01451

\section{Yes}

52.53

Reportable Quantity:

RQ Limit Fraction:

Shipping Papers and Labels: Isotope Number of A2s

+ Am-241

5.473

3.107

1.696

0.9257

0.7934

0.2295

0.1553

0.07032

Cs-137

Fraction of A2s

0.4394

0.2495

0.1362

0.07433

0.0637

0.01843

0.01247

0.005646
(Fissile excepted, ACEMs $>30 \times$ rad limits)

(A2s/gm > 0.0001)

(A2s/gm $<=0.002)$

$(A 2 s<=3000$, Activity $<=1000 \mathrm{TBq})$

(Contains fissile isotopes per 49 CFR 173.403)

(Fissile isotopes $<=15$ grams, container + contents

+

Radionuclides comprising less than $0.1 \%$ of the total A2s are not shown in the list.

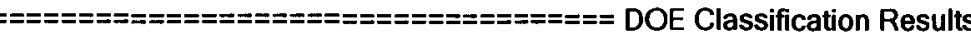

(RQs $>=1.0)$

RQs (Number of RQs)

- DOE classification calculations are made at the end of the user-specified decay time.

DOE-STD-1027 Category Determination:

Category:

Cat 2 Limit Fraction:

$<$ Cat 3

0.005979

$($ Cat3s $<=1.0)$

Cat 3 Limit Fraction:

0.7525

Cumulative Fraction of $\mathrm{A} 2 \mathrm{~s}$

0.4394

0.6889

0.8251

0.8994

0.9632

0.9816

0.994

0.9997

The DOE-STD-1027 category determination is based on dose-related limits.

The user must apply any criticality-related limits separately.

Dose-Equivalent Curies:

ICRP-72 DE-Ci: 
HNF-43821 Rev. 3

FGR-11 DE-Ci:

TRU Waste Determination:

TRU Waste:

TRU Activity:

WIPP Quantities:

FGE Value:

PE-Ci Value:
0.3373

Yes

29630

$\mathrm{nCi} / \mathrm{g}$

(TRU activity > $100 \mathrm{nCi} / \mathrm{gm}$ )
4.457

0.3297

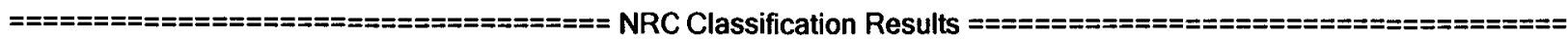

* NRC classification calculations are made at the end of the user-specified decay time.

NRC Container Category:

Container Category:

LSA-l:

LSA-II:

LSA-III:

Total Activity:

A2 Limit Fraction:

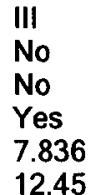

$\mathrm{Ci}$

A2s

Hydrogen/Helium Gas Results

* Hydrogen gas calculations are made at the end of the user-specified seal time.

Hydrogen Gas:

H2 Concentration:

H2 Moles:

$0 \quad$ moles

$\mathrm{H} 2$ Volume :

0

H2 Rate When Sealed: $\quad 0.08154$

H2 Rate When Opened: $\quad 0.08154$

$\mathrm{cm}^{\wedge} 3$

$\mathrm{cm}^{\wedge} 3 / \mathrm{hr}$

$\mathrm{cm}^{\wedge} 3 / \mathrm{hr}$

$(0 \mathrm{C}, 101.325 \mathrm{kPa})$

(0 C, $101.325 \mathrm{kPa})$

(0 C, $101.325 \mathrm{kPa}$ )

Helium Gas:

He Concentration:

He Moles :

He Volume :

0

He Rate When Sealed:

0

He Rate When Opened:

1.486E-06

$1.486 \mathrm{E}-06$

Pressure When Opened:

Partial Pressure ( $\mathrm{H} 2)$ :

Partial Pressure $(\mathrm{He})$ :

Partial Pressure (O2):

Total Pressure $(\mathrm{H} 2+\mathrm{He}+\mathrm{Air})$ :

Total Pressure $(\mathrm{H} 2+\mathrm{He}+\mathrm{O} 2+$ Air $)$ :

0

0

101.3

101.3
$\%$

moles

$\mathrm{cm}^{\wedge} 3$

$\mathrm{cm}^{\wedge} 3 / \mathrm{hr}$

$\mathrm{cm}^{\wedge} 3 / \mathrm{hr}$

(0 C, $101.325 \mathrm{kPa})$

(0 C, $101.325 \mathrm{kPa}$ )

$(0 \mathrm{C}, 101.325 \mathrm{kPa})$

$\begin{array}{ll}\begin{array}{l}\mathrm{kPa} \\ \mathrm{kPa} \\ \mathrm{kPa}\end{array} & \\ \mathrm{kPa} & \\ \mathrm{kPa} & \text { (if } \mathrm{H} 20 \text { present in waste) } \\ & \end{array}$ 


\section{HNF-43821 Rev. 3}

\subsection{2 $600 \mathrm{~mL}$ Design Basis Radcalc 4.1 Results Decayed Nominal 15 day}

Radcalc 4.1: D:IHanford120091H2GENhrad filesloriginal_0_6L_Design_15day_rev.rad

Performed By: Don Riley

Checked By: Alvia Bridges

aEB $\$ / 24 / 10$

Input Information

Comments:

0.6L Sludge, Design Basis

Decayed from $5 / 31 / 1998$ by 15 days.

Sludge: HNF-41051 Rev. 5, Table 2-2a Settler Source Term (50/50 KE/KW)

Water: KE Canister Water, Table 4-1, HNF-SD-SNF-TI-009, Vol 2, Rev 4

Initial Source Data:

$\begin{array}{llll}\text { Isotope } & \mathrm{Ci} & \mathrm{Gm} & \mathrm{TBq} \\ \text { Co-60 } & 6.350 \mathrm{E}-03 & 5.611 \mathrm{E}-06 & 2.350 \mathrm{E}-04 \\ \text { Sr-90 } & 2.460 \mathrm{E}+00 & 1.781 \mathrm{E}-02 & 9.102 \mathrm{E}-02 \\ \text { Y-90 } & 2.460 \mathrm{E}+00 & 4.524 \mathrm{E}-06 & 9.102 \mathrm{E}-02 \\ \text { Tc-99 } & 9.300 \mathrm{E}-04 & 5.506 \mathrm{E}-02 & 3.441 \mathrm{E}-05 \\ \text { Cs-134 } & 1.490 \mathrm{E}-04 & 1.153 \mathrm{E}-07 & 5.513 \mathrm{E}-06 \\ \text { Cs-137 } & 1.490 \mathrm{E}+00 & 1.714 \mathrm{E}-02 & 5.513 \mathrm{E}-02 \\ \text { Ba-137m } & 1.400 \mathrm{E}+00 & 2.601 \mathrm{E}-09 & 5.180 \mathrm{E}-02 \\ \text { Eu-152 } & 2.060 \mathrm{E}-04 & 1.184 \mathrm{E}-06 & 7.622 \mathrm{E}-06 \\ \text { Eu-154 } & 1.930 \mathrm{E}-02 & 7.140 \mathrm{E}-05 & 7.141 \mathrm{E}-04 \\ \text { Eu-155 } & 9.640 \mathrm{E}-03 & 1.986 \mathrm{E}-05 & 3.567 \mathrm{E}-04 \\ \mathrm{U}-234 & 3.010 \mathrm{E}-04 & 4.842 \mathrm{E}-02 & 1.114 \mathrm{E}-05 \\ \text { U-235 } & 1.030 \mathrm{E}-05 & 4.766 \mathrm{E}+00 & 3.811 \mathrm{E}-07 \\ \text { U-236 } & 3.400 \mathrm{E}-05 & 5.320 \mathrm{E}-01 & 1.258 \mathrm{E}-06 \\ \mathrm{U}-238 & 2.100 \mathrm{E}-04 & 6.248 \mathrm{E}+02 & 7.770 \mathrm{E}-06 \\ \text { Np-237 } & 1.640 \mathrm{E}-05 & 2.327 \mathrm{E}-02 & 6.068 \mathrm{E}-07 \\ \text { Pu-238 } & 2.350 \mathrm{E}-02 & 1.372 \mathrm{E}-03 & 8.695 \mathrm{E}-04 \\ \text { Pu-239 } & 8.400 \mathrm{E}-02 & 1.354 \mathrm{E}+00 & 3.108 \mathrm{E}-03 \\ \text { Pu-240 } & 4.590 \mathrm{E}-02 & 2.023 \mathrm{E}-01 & 1.698 \mathrm{E}-03 \\ \text { Pu-241 } & 2.630 \mathrm{E}+00 & 2.541 \mathrm{E}-02 & 9.731 \mathrm{E}-02 \\ \text { Pu-242 } & 2.070 \mathrm{E}-05 & 5.235 \mathrm{E}-03 & 7.659 \mathrm{E}-07 \\ \text { Am-241 } & 1.130 \mathrm{E}-01 & 3.298 \mathrm{E}-02 & 4.181 \mathrm{E}-03 \\ & & & \\ \text { Total Activity: } & 1.074 \mathrm{E}+01 & & 3.975 \mathrm{E}-01\end{array}$

* Radionuclides with an A1/A2 fraction of less than 0.001 will not be shown in the output.

Container Data:

Container Void Volume: $\quad 0.0542 \quad \mathrm{~m}^{\wedge} 3$

Container Mass:

Mass of solid beryllium, lead, graphite, and hydrogenous material enriched with deuterium:

Gross Mass:

$\begin{array}{ll}0.0542 & \mathrm{~m}^{\wedge} 3 \\ 5806 & \mathrm{~kg} \\ 0 & \mathrm{~kg} \\ 5816 & \mathrm{~kg}\end{array}$

Waste Data:

Waste Form:

Waste State:

Waste Volume:

Waste Mass:

Mass of solid lead:

Mass of solid beryllium, graphite, and hydrogenous material enriched with deuterium: Waste Void Volume:

$\begin{array}{ll}\begin{array}{l}\text { Normal } \\ \text { Solid }\end{array} & \\ 0.0041 & \mathrm{~m}^{\wedge} 3 \\ 10.1 & \mathbf{k g} \\ 0 & \mathbf{k g} \\ & \\ 0 & \mathbf{k g} \\ \mathbf{0} & \mathrm{m}^{\wedge} 3\end{array}$

Decay Time Data:

Time to decay source before sealing: 15 day

$\begin{array}{lll}\text { Time container is sealed: } & 0 & \text { day }\end{array}$

Gamma Absorption Model:

Gamma Abs Model:

$100 \%$ Gamma Absorption 
HNF-43821 Rev. 3

G Value Data:
G Alpha
G Beta
G Gamma
1.64

$\begin{array}{ll}0.24 & 0.072 \\ G \text { values entered by the user. }\end{array}$

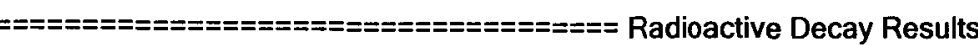

Decayed Source:

\begin{tabular}{|c|c|c|c|}
\hline Isotope & $\mathrm{Ci}$ & $\mathrm{Gm}$ & TBq \\
\hline $\begin{array}{l}\text { Co-60 } \\
\text { Sr-90 }\end{array}$ & $\begin{array}{l}6.316 \mathrm{E}-03 \\
2.458 \mathrm{E}+00\end{array}$ & $\begin{array}{l}5.581 \mathrm{E}-06 \\
1779 \mathrm{~F}-02\end{array}$ & $\begin{array}{l}2.337 \mathrm{E}-04 \\
9.093 \mathrm{E}-02\end{array}$ \\
\hline$Y-90$ & $2.458 \mathrm{E}+00$ & 4.521E-06 & $9.095 \mathrm{E}-02$ \\
\hline Tc-99 & $9.300 \mathrm{E}-04$ & $5.506 \mathrm{E}-02$ & $3.441 E-05$ \\
\hline Xe-134 & 1.149E-27 & 4.733E-15 & $4.251 \mathrm{E}-29$ \\
\hline Cs-134 & $1.470 \mathrm{E}-04$ & 1.137E-07 & $5.438 \mathrm{E}-06$ \\
\hline Cs-137 & $1.489 \mathrm{E}+00$ & 1.712E-02 & $5.508 \mathrm{E}-02$ \\
\hline Ba-137m & $1.405 E+00$ & $2.611 \mathrm{E}-09$ & 5.199E-02 \\
\hline $\mathrm{Nd}-144$ & 1.116E-55 & $1.029 \mathrm{E}-43$ & $4.130 \mathrm{E}-57$ \\
\hline Sm-148 & 2.693E-38 & $8.915 \mathrm{E}-26$ & $9.965 \mathrm{E}-40$ \\
\hline Eu-152 & $2.056 \mathrm{E}-04$ & 1.181E-06 & 7.606E-06 \\
\hline Eu-154 & 1.924E-02 & 7.117E-05 & 7.117E-04 \\
\hline Eu-155 & $9.582 E-03$ & $1.974 \mathrm{E}-05$ & $3.546 \mathrm{E}-04$ \\
\hline Gd-152 & $1.513 \mathrm{E}-20$ & $6.945 \mathrm{E}-10$ & 5.599E-22 \\
\hline $\mathrm{Hg}-206$ & $3.482 E-27$ & $3.109 E-35$ & $1.288 \mathrm{E}-28$ \\
\hline TI-206 & $8.126 \mathrm{E}-26$ & $3.741 \mathrm{E}-34$ & $3.007 \mathrm{E}-27$ \\
\hline TI-207 & $1.425 \mathrm{E}-16$ & $7.482 \mathrm{E}-25$ & $5.272 \mathrm{E}-18$ \\
\hline TI-208 & 1.037E-22 & 3.503E-31 & $3.838 \mathrm{E}-24$ \\
\hline TI-209 & 4.017E-22 & $9.822 \mathrm{E}-31$ & $1.486 \mathrm{E}-23$ \\
\hline TI-210 & $1.088 \mathrm{E}-19$ & $1.580 \mathrm{E}-28$ & $4.027 \mathrm{E}-21$ \\
\hline $\mathrm{Pb}-209$ & 1.753E-20 & $3.804 \mathrm{E}-27$ & $6.488 \mathrm{E}-22$ \\
\hline $\mathrm{Pb}-210$ & $1.836 \mathrm{E}-19$ & 2.390E-21 & $6.795 \mathrm{E}-21$ \\
\hline $\mathrm{Pb}-211$ & $1.431 \mathrm{E}-16$ & $5.798 \mathrm{E}-24$ & $5.296 \mathrm{E}-18$ \\
\hline $\mathrm{Pb}-212$ & $2.934 \mathrm{E}-22$ & $2.112 \mathrm{E}-28$ & $1.086 \mathrm{E}-23$ \\
\hline $\mathrm{Pb}-214$ & $5.201 \mathrm{E}-16$ & $1.586 \mathrm{E}-23$ & $1.924 \mathrm{E}-17$ \\
\hline $\mathrm{Bi}-209$ & 4.523E-42 & $5.024 \mathrm{E}-26$ & $1.674 E-43$ \\
\hline $\mathrm{Bi}-210$ & $5.900 \mathrm{E}-20$ & $4.755 \mathrm{E}-25$ & $2.183 \mathrm{E}-21$ \\
\hline $\mathrm{Bi}-211$ & $1.431 \mathrm{E}-16$ & $3.483 \mathrm{E}-25$ & $5.293 \mathrm{E}-18$ \\
\hline $\mathrm{Bi}-212$ & $2.889 \mathrm{E}-22$ & $1.972 E-29$ & $1.069 \mathrm{E}-23$ \\
\hline $\mathrm{Bi}-213$ & $1.861 \mathrm{E}-20$ & $9.610 \mathrm{E}-28$ & $6.885 \mathrm{E}-22$ \\
\hline Bi-214 & 5.184E-16 & $1.174 \mathrm{E}-23$ & $1.918 \mathrm{E}-17$ \\
\hline $\mathrm{Bi}-215$ & $3.818 \mathrm{E}-21$ & $3.230 \mathrm{E}-29$ & $1.413 \mathrm{E}-22$ \\
\hline Po-210 & $8.017 \mathrm{E}-22$ & $1.784 \mathrm{E}-25$ & $2.966 \mathrm{E}-23$ \\
\hline Po-211 & $3.905 E-19$ & $3.769 \mathrm{E}-30$ & $1.445 \mathrm{E}-20$ \\
\hline Po-212 & 1.851E-22 & $1.036 \mathrm{E}-39$ & $6.848 \mathrm{E}-24$ \\
\hline Po-213 & 1.821E-20 & $1.444 \mathrm{E}-36$ & $6.738 \mathrm{E}-22$ \\
\hline Po-214 & $5.183 E-16$ & $1.609 \mathrm{E}-30$ & $1.918 \mathrm{E}-17$ \\
\hline Po-215 & $1.445 \mathrm{E}-16$ & $4.902 E-30$ & $5.347 E-18$ \\
\hline Po-216 & $3.416 \mathrm{E}-22$ & $9.810 \mathrm{E}-34$ & $1.264 \mathrm{E}-23$ \\
\hline Po-218 & $5.225 \mathrm{E}-16$ & 1.877E-24 & $1.933 \mathrm{E}-17$ \\
\hline At-215 & $5.780 \mathrm{E}-22$ & $1.102 E-36$ & $2.139 \mathrm{E}-23$ \\
\hline At-217 & $1.888 \mathrm{E}-20$ & $1.173 E-32$ & $6.985 \mathrm{E}-22$ \\
\hline At-218 & $9.928 \mathrm{E}-20$ & $2.878 E-30$ & $3.673 \mathrm{E}-21$ \\
\hline At-219 & $3.940 \mathrm{E}-21$ & $4.130 \mathrm{E}-30$ & $1.458 \mathrm{E}-22$ \\
\hline Rn-217 & $2.265 \mathrm{E}-24$ & $2.353 E-38$ & $8.381 E-26$ \\
\hline Rn-218 & $9.928 \mathrm{E}-23$ & $6.715 \mathrm{E}-35$ & $3.673 \mathrm{E}-24$ \\
\hline Rn-219 & $1.445 \mathrm{E}-16$ & $1.111 \mathrm{E}-26$ & $5.347 \mathrm{E}-18$ \\
\hline $\mathrm{Rn}-2$ & $3.416 \mathrm{E}-22$ & $3.717 \mathrm{E}-31$ & $1.264 \mathrm{E}-23$ \\
\hline $\mathrm{Rn}-222$ & $5.228 \mathrm{E}-16$ & 3.399E-21 & $1.934 \mathrm{E}-17$ \\
\hline $\mathrm{Fr}-221$ & $1.888 \mathrm{E}-20$ & $1.087 \mathrm{E}-28$ & $6.985 \mathrm{E}-22$ \\
\hline $\mathrm{Fr}-223$ & 6.568E-17 & $1.698 \mathrm{E}-24$ & $2.430 \mathrm{E}-18$ \\
\hline Ra-223 & $1.445 \mathrm{E}-16$ & $2.821 \mathrm{E}-21$ & 5.347E-18 \\
\hline Ra-224 & $3.416 \mathrm{E}-22$ & 2.134E-27 & $1.264 \mathrm{E}-23$ \\
\hline Ra-225 & $1.038 \mathrm{E}-19$ & $2.647 \mathrm{E}-24$ & $3.840 \mathrm{E}-21$ \\
\hline & $1.011 \mathrm{E}-15$ & $1.023 \mathrm{E}-15$ & $3.740 \mathrm{E}-17$ \\
\hline Ra-228 & $1.702 \mathrm{E}-19$ & $6.244 \mathrm{E}-22$ & $6.299 \mathrm{E}-21$ \\
\hline$A c-225$ & 1.891E-20 & $3.258 \mathrm{E}-25$ & $6.995 \mathrm{E}-22$ \\
\hline
\end{tabular}


HNF-43821 Rev. 3

$\begin{array}{llll}\text { Ac-227 } & 4.774 \mathrm{E}-15 & 6.601 \mathrm{E}-17 & 1.767 \mathrm{E}-16 \\ \text { Ac-228 } & 1.621 \mathrm{E}-19 & 7.252 \mathrm{E}-26 & 5.996 \mathrm{E}-21 \\ \text { Th-227 } & 7.074 \mathrm{E}-16 & 2.302 \mathrm{E}-20 & 2.617 \mathrm{E}-17 \\ \text { Th-228 } & 7.826 \mathrm{E}-22 & 9.547 \mathrm{E}-25 & 2.896 \mathrm{E}-23 \\ \text { Th-229 } & 6.645 \mathrm{E}-19 & 3.125 \mathrm{E}-18 & 2.459 \mathrm{E}-20 \\ \text { Th-230 } & 1.136 \mathrm{E}-10 & 5.513 \mathrm{E}-09 & 4.205 \mathrm{E}-12 \\ \text { Th-231 } & 1.030 \mathrm{E}-05 & 1.938 \mathrm{E}-11 & 3.811 \mathrm{E}-07 \\ \text { Th-232 } & 6.889 \mathrm{E}-17 & 6.282 \mathrm{E}-10 & 2.549 \mathrm{E}-18 \\ \text { Th-234 } & 7.361 \mathrm{E}-05 & 3.178 \mathrm{E}-09 & 2.723 \mathrm{E}-06 \\ \text { Pa-231 } & 8.035 \mathrm{E}-12 & 1.701 \mathrm{E}-10 & 2.973 \mathrm{E}-13 \\ \text { Pa-233 } & 5.242 \mathrm{E}-06 & 2.526 \mathrm{E}-10 & 1.939 \mathrm{E}-07 \\ \text { Pa-234 } & 1.080 \mathrm{E}-07 & 5.467 \mathrm{E}-14 & 3.995 \mathrm{E}-09 \\ \text { Pa-234m } & 7.360 \mathrm{E}-05 & 1.072 \mathrm{E}-13 & 2.723 \mathrm{E}-06 \\ \text { U-233 } & 4.985 \mathrm{E}-13 & 5.175 \mathrm{E}-11 & 1.844 \mathrm{E}-14 \\ \text { U-234 } & 3.010 \mathrm{E}-04 & 4.842 \mathrm{E}-02 & 1.114 \mathrm{E}-05 \\ \text { U-235 } & 1.030 \mathrm{E}-05 & 4.766 \mathrm{E}+00 & 3.811 \mathrm{E}-07 \\ \text { U-235m } & 8.395 \mathrm{E}-02 & 2.728 \mathrm{E}-09 & 3.106 \mathrm{E}-03 \\ \text { U-236 } & 3.400 \mathrm{E}-05 & 5.321 \mathrm{E}-01 & 1.258 \mathrm{E}-06 \\ \text { U-237 } & 5.077 \mathrm{E}-05 & 6.221 \mathrm{E}-10 & 1.878 \mathrm{E}-06 \\ \text { U-238 } & 2.100 \mathrm{E}-04 & 6.248 \mathrm{E}+02 & 7.770 \mathrm{E}-06 \\ \text { Np-237 } & 1.640 \mathrm{E}-05 & 2.327 \mathrm{E}-02 & 6.069 \mathrm{E}-07 \\ \text { Pu-238 } & 2.349 \mathrm{E}-02 & 1.372 \mathrm{E}-03 & 8.692 \mathrm{E}-04 \\ \text { Pu-239 } & 8.400 \mathrm{E}-02 & 1.354 \mathrm{E}+00 & 3.108 \mathrm{E}-03 \\ \text { Pu-240 } & 4.590 \mathrm{E}-02 & 2.023 \mathrm{E}-01 & 1.698 \mathrm{E}-03 \\ \text { Pu-241 } & 2.625 \mathrm{E}+00 & 2.536 \mathrm{E}-02 & 9.712 \mathrm{E}-02 \\ \text { Pu-242 } & 2.070 \mathrm{E}-05 & 5.235 \mathrm{E}-03 & 7.659 \mathrm{E}-07 \\ \text { Am-241 } & 1.132 \mathrm{E}-01 & 3.303 \mathrm{E}-02 & 4.187 \mathrm{E}-03 \\ & & & \\ \text { Total Activity: } & 1.082 \mathrm{E}+01 & & 4.004 \mathrm{E}-01 \\ \text { w/o Daughters: } & 6.959 \mathrm{E}+00 & & 2.575 \mathrm{E}-01 \\ & & & \\ \text { Heat Generated at Time Zero: } & 0.03226 & \text { W } \\ \text { Heat Generated When Sealed: } & 0.03227 & \text { W } \\ \text { Heat Generated When Opened: } & 0.03227 & \text { W } \\ & & & \end{array}$

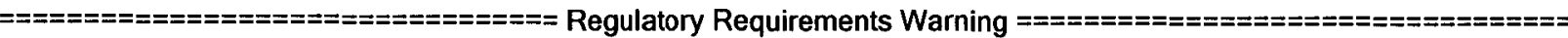

Radcalc utilizes numerically based criteria to classify packages against the regulations. Many regulations also include subjective criteria that Radcalc does not consider. The user must check to ensure that all requirements in the regulations are met.

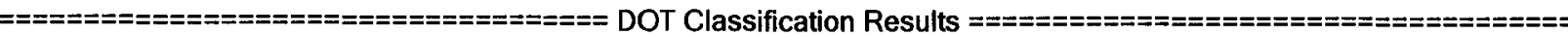

* DOT classification calculations are made at the end of the user-specified decay time.

Radioactive Determination:

Radioactive:

Yes

ACEM Limit Fraction:

ALEC Limit Fraction:

1749000

18400000

ACEMs

ACEMs and ALECs > 1.0)

- This package is not exempt from 49 CFR Subchapter C

Effective A2s for Mixture:

$2.139 E+10$

$\mathrm{Bq}$

Type Determination:

Type:

A2 Limit Fraction:

B

12.04

A2s

$(A 2 s>1.0)$

(Number of A2s)

Limited Quantity Determination: Limited Quantity: No Activity:

12.04

10.82

0.4004

Fissile:

Fissile Excepted:

Yes

Yes (b)
A2

$\mathrm{Ci}$

$\mathrm{TBq}$
(Solid, activity > 0.001 A2)

LSA Determination: 
HNF-43821 Rev. 3

LSA-I:

LSA-II:

LSA-III:

Specific Activity:

HRCQ Determination:

HRCQ:

A2 Limit Fraction:

Activity:

Fissile Determination:

Fissile:
No

No

Yes

0.001192

0.001071

A2/gm

$\mathrm{Ci} / \mathrm{gm}$

No

12.04

10.82

0.4004

A2s

$\mathrm{Ci}$

TBq
(Fissile excepted, ACEMs $>30 \times$ rad limits)

(A2s/gm > 0.0001)

$(\mathrm{A} 2 \mathrm{~s} / \mathrm{gm}<=0.002$ )

(A2s $<=3000$, Activity $<=1000 \mathrm{TBq}$ )

(Contains fissile isotopes per 49 CFR 173.403)

(Fissile isotopes $<=15$ grams, container + contents

Fissile Excepted Determination:

Fissile Excepted:

Yes

Yes (b)

solid non-fissile $>=1.229 \mathrm{E}+03$ grams)

Fissile Mass:

6.146

gm

Container beryllium, lead, graphite, and hydrogenous material enriched with deuterium:

Container Mass:

Waste lead:

Waste beryllium, graphite,

and hydrogenous material

enriched with deuterium:

Waste Mass:

Solid Non-Fissile Mass:

Total Uranium Mass:

U-233 Mass:

U-235 Mass:

Uranium Enrichment:

Total Plutonium Mass:

Pu-239 Mass:

Pu-241 Mass:

0

5806000

0

gm

$\mathrm{gm}$

gm

0

gm

10100

5816000

630.1

5.175E-11

4.766

0.7564

1.589

1.354

0.02536

$\mathrm{gm}$

$\mathrm{gm}$

$\mathrm{gm}$

$\mathrm{gm}$

gm

$\%$

gm

gm

gm

Reportable Quantity Determination:

Reportable Quantity:

RQ Limit Fraction:

Yes

57.09

RQs

(RQs > = 1.0)

(Number of RQs)

Shipping Papers and Labels:

Isotope Number of A2s

$+\mathrm{Am}-241 \quad 4.187$

Fraction of A2s

Cumulative A2s

Cumulative Fraction of $\mathrm{A} 2 \mathrm{~s}$

+ Pu-239

3.108

0.3479

0.2582

4.187

0.3479

0.1411

7.295

0.6061

+ Pu-240 1.698

$+\mathrm{Pu}-241 \quad 1.619$

$+\quad \mathrm{Pu}-238$

0.8692

0.1345

8.993

0.7472

Sr-90

0.07221

10.61

0.8817

11.48

0.02518

11.78

0.9539

U-235m

0.1553

0.0129

Cs-137

0.0918

0.007626

11.94

0.979

0.992

0.9996

+ Contains $95 \%$ of the total A2s and must be included per 49 CFR 173.433

* Radionuclides comprising less than $0.1 \%$ of the total A2s are not shown in the list.

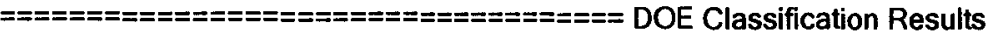

* DOE classification calculations are made at the end of the user-specified decay time.

DOE-STD-1027 Category Determination:
Category:
$<$ Cat 3
0.005803
Cat 2 Limit Fraction:
0.7678

$($ Cat3s $<=1.0)$

* The DOE-STD-1027 category determination is based on dose-related limits.

The user must apply any criticality-related limits separately.

Dose-Equivalent Curies:

ICRP-72 DE-Ci: 
HNF-43821 Rev. 3

FGR-11 DE-Ci:

TRU Waste Determination:

TRU Waste:

TRU Activity:

WIPP Quantities:

FGE Value:

PE-Ci Value:
0.3267

Yes

26400

$\mathrm{nCi} / \mathrm{g}$

(TRU activity > $100 \mathrm{nCi} / \mathrm{gm}$ )

4.482

0.3182

* NRC classification calculations are made at the end of the user-specified decay time.

NRC Container Category:

Container Category:

LSA-I:

LSA-II:

LSA-III:

Total Activity:

A2 Limit Fraction:

III
No
No
Yes
10.82
12.04

$\mathrm{Ci}$

A2s

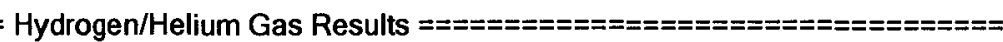

* Hydrogen gas calculations are made at the end of the user-specified seal time.

Hydrogen Gas:

H2 Concentration:

$0 \quad \%$

$\mathrm{H} 2$ Moles :

H2 Volume :

H2 Rate When Sealed: $\quad 0.1002$

H2 Rate When Opened: 0.1002

moles

$\mathrm{cm}^{\wedge} 3$

$\mathrm{cm}^{\wedge} 3 / \mathrm{hr}$

$\mathrm{cm}^{\wedge} 3 / \mathrm{hr}$

(0 C, $101.325 \mathrm{kPa})$

(0 C, $101.325 \mathrm{kPa})$

(0 C, 101.325 kPa)

Helium Gas:

He Concentration:

He Moles :

He Volume :

0

0

0

He Rate When Sealed: $\quad 1.325 E-06$

He Rate When Opened: $1.325 \mathrm{E}-06$

$\%$

moles

$\mathrm{cm}^{\wedge} 3$

$\mathrm{cm}^{\wedge} 3 / \mathrm{hr} \quad(0 \mathrm{C}, 101.325 \mathrm{k}$

$\mathrm{cm}^{\wedge} 3 / \mathrm{hr} \quad(0 \mathrm{C}, 101.325 \mathrm{kPa})$

Pressure When Opened:

Partial Pressure ( $\mathrm{H} 2)$ :

Partial Pressure $(\mathrm{He})$ :

Partial Pressure (O2):

Total Pressure $(\mathrm{H} 2+\mathrm{He}+\mathrm{Air})$ :

0

0

101.3

Total Pressure ( $\mathrm{H} 2+\mathrm{He}+\mathrm{O} 2+$ Air):
$\mathrm{kPa}$

$\mathrm{kPa}$

$\mathrm{kPa}$ (if $\mathrm{H} 20$ present in waste)

$\mathrm{kPa}$

$\mathrm{kPa}$ (if $\mathrm{H} 20$ present in waste) 
HNF-43821 Rev. 3

7.8 PNNL Supplied Data on Plutonium Dioxide Enthalpies and Free Energies of Reaction

\begin{tabular}{rllll} 
& & \multicolumn{2}{c}{$\mathrm{kJ} / \mathrm{mole}$} & \\
Formula & Compound & $\Delta \mathrm{H}_{\mathrm{f}, 298}$ & $\Delta \mathrm{G}_{\mathrm{f}, 298}^{0}$ & data source \\
$\mathrm{UO}_{2}$ & uraninite & -1084.9 & -1031.7 & Wagman \\
$\mathrm{PuO}_{2}$ & plutonium dioxide & -1055.8 & -998.113 & Guillaumont \\
$\mathrm{H}_{2} \mathrm{O}$ & water & -285.830 & -237.129 & Wagman
\end{tabular}

Ref. Thermo data from:

D. D. Wagman, W. H. Evans, V. B. Parker, R. H. Schumm, I. Halow, S. M. Bailey, K. L. Churney, and R. L. Nuttall. 1982. "The NBS Tables of Chemical Thermodynamic Properties - Selected Values for

Wagman Inorganic and C1 and C2 Organic Substances in SI Units." Journal of Physical and Chemical Reference Data 11 (Supplement 2).

Available at: $h$ ttp://www.nist.gov/srd/PDFfiles/jpcrdS2Vol11.pdf

Guillaumont, Robert, Thomas Fanghänel, Volker Neck, Jean Fuger,

Guillaumont

Donald A. Palmer, Ingmar Grenthe, Malcolm H. Rand. 2003. Update

on the Chemical Thermodynamics of Uranium, Neptunium.

Plutonium, Americium, and Technetium. Elsevier, Amsterdam.

\begin{tabular}{cllll} 
Reactions & \multicolumn{2}{c}{$\mathrm{kJ} /$ reaction as-written } & \multicolumn{2}{c}{$\mathrm{kJ} / \mathrm{mole} \mathrm{U}$ or $\mathrm{Pu}$} \\
$\mathrm{U}+2 \mathrm{H}_{2} \mathrm{O} \rightarrow \mathrm{UO}_{2}+2 \mathrm{H}_{2}$ & -513.24 & -557.44 & -513.24 & -557.44 \\
$\mathrm{Pu}+2 \mathrm{H}_{2} \mathrm{O} \rightarrow \mathrm{PuO}_{2}+2 \mathrm{H}_{2}$ & -484.14 & -523.86 & -484.14 & -523.86
\end{tabular}

